\title{
( Tort Compensation in the United States and aße England: Goal or Means?
}

\section{Boaz Segal*}

Faculty of Law, Sapir Academic College, ISRAEL

E-mail for correspondence: boaz.segal41@gmail.com

\begin{abstract}
The modern state exists and acts on behalf of its citizens. No longer is it the state of a sole ruler acting on his or her own behalf and for his or her own sake. Rather, it is a civil state whose role is to preserve the rights of its citizens and to maximize their welfare. An important instrument for the goal of realizing these roles is the government authority held by the state. Consequently, the modern state exercises extensive government authority in social and economic life. The widening of the areas of activity in which it is involved and over which it exercises its authority raises the question of the desirable scope of state liability for the negligent exercise of this authority. In this paper, I analyze the scope of tort liability of public agencies and public authorities in the United States and England. The innovation proposed in this article is twofold for, although the scope of liability of public agencies has been extensively surveyed and analyzed in the academic literature, these surveys and analyses were for the most part conducted by means of organizing the development of the relevant case law along a timeline. This article adopts a different approach, examining the scope of liability of public agencies according to their areas of activity. Accordingly, the abundant court judgments are classified into varied areas of government activity. This technique allows for fine, precise inferences to be drawn with regard to the level of liability of public agencies. It can be stated already at this stage that, as a whole, the fundamental conclusion of this article is that in both the United States and England the remnants of the traditional doctrine, that of sovereign or crown immunity, are marked. An analysis of the law in these countries shows that to this day, public agencies still enjoy extensive protections against tort claims and that the general approach there has always been to limit liability. The second innovation included in this article is, in a nutshell, the suggestion of a possible reason for the prevalence of this doctrine in the United States and England. I argue that this reason may be the manner in which each judicial system perceives the role of the instrument of tort compensation. Accordingly, I contend that compensation is perceived in the United States and England as a means to achieve the goals of tort law, rather than as an independent goal standing on its own merit.
\end{abstract}

Keywords: Tort compensation, public agencies, public authorities, scope of public agency liability

\section{PART A: INTRODUCTION}

The modern state exists and acts on behalf of its citizens. No longer is it the state of a sole ruler acting on his or her own behalf and for his or her own sake. Rather, it is a civil state whose role is to preserve the rights of its citizens and to maximize their welfare. An important instrument for the goal of realizing these roles is the government authority held by the state. Consequently, the modern state exercises extensive government authority in social and economic life. The widening of the areas of activity in which it is involved and over which it exercises its authority raises the question of the desirable scope of state liability for the

* Dr. Boaz Segal is a lecturer at Sapir Academic College School of Law and at Zefat Academic College School of Law. A special thank you is extended to Professor Barak Medina, Rector of the Hebrew University of Jerusalem, and to Israel Supreme Court Justice Prof. Ofer Grosskopf for their important, illuminating comments on earlier drafts of this article. 
negligent exercise of this authority. In this paper, I analyze the scope of tort liability of public agencies and public authorities in the United States and England. The innovation proposed in this article is twofold for, although the scope of liability of public agencies has been extensively surveyed and analyzed in the academic literature, these surveys and analyses were for the most part conducted by means of organizing the development of the relevant case law along a timeline. This article adopts a different approach, examining the scope of liability of public agencies according to their areas of activity. Accordingly, the abundant court judgments are classified into varied areas of government activity. This technique allows for fine, precise inferences to be drawn with regard to the level of liability of public agencies, both globally and in Israel. ${ }^{1}$ It can be stated already at this stage that, as a whole, the fundamental conclusion of this article is that in both the United States and England the remnants of the traditional doctrine, that of sovereign or crown immunity, are marked. An analysis of the law in these countries shows that to this day, public agencies still enjoy extensive protections against tort claims and that the general approach there has always been to limit liability.

The second innovation included in this article is, in a nutshell, the suggestion of a possible reason for the prevalence of this doctrine in the United States and England. I argue that this reason may be the manner in which each judicial system perceives the role of the instrument of tort compensation. Accordingly, I contend that compensation is perceived in the United States and England as a means to achieve the goals of tort law, rather than as an independent goal standing on its own merit.

With this in mind, the parts of this article - and the course of the overall argumentation -develops as follows:

I commence, in Part B, by analyzing United States law. First, Part B.1 presents the legislative framework. This is followed by a presentation of relevant court judgments, in Part B.2. Finally, Part B.3 contains an analysis of the data collected in the first two subparts, from which it transpires that the scope of liability of public agencies in the United States is very limited. Next, in Part C, I analyze English common law. This part, too, opens, in Part C.1, with an introduction to the country's legislative framework, followed, in Part C.2, by a presentation of the multiple relevant judgments handed down by the English courts. An analysis of the data in these two subparts leads me, in Part C.3, to the conclusion that in many instances in England, too, the remnants of the traditional approach siding with the doctrine of sovereign or crown immunity -

In view of my analysis of the rich case law, I present the abundant information in tables, according to the areas of activity of the modern state. Each area of activity is assigned a separate table, containing the following data: case name (ordered according to the names of the parties); description of alleged government negligence; court decision; indices relevant to the question whether there was room to impose are conspicuous, and is implemented in its courts by means of diverse doctrines and legal instruments. The overall conclusion, in Part $\mathbf{D}$, winds up the article.

\section{Part B: Tort Law and Public Agencies in the United States}

The purpose of this part is to identify the courses that the courts in the United States chose to follow, and to estimate the scope of tort liability of public agencies in that country today. It can be generalized and stated, already at this stage, that my conclusion will be that the scope of public agency liability in the United States is limited, and that the law of that country accords considerable weight to statutory immunity and to liability-limiting policy considerations. In short, the remnants of the traditional doctrine of sovereign immunity are notable in the United States.

Consequently, the survey of United States law below will reveal that, today too, it tends to extend broad protection to public agencies against tort claims, and its general approach to their activity is one that limits their liability. This approach is based on concern about harming the principle of the separation of powers, the over-deterrence of agencies, the unleashing of a torrent of claims, including frivolous ones, as well as the disruption of ongoing government activity. This liability-limiting approach is reflected at all three levels: federal, state and municipal. Limitation of the scope of liability of public agencies is implemented in United States courts either by cases being dismissed without prejudice on the grounds that the state enjoys immunity in the matter in question, or by their rejection on the strength of considerations of policy discussed below, which carry considerable weight in the question of the existence of the duty of care (in such cases, a deliberation is required). This distinction, between the agency immunity and between liability exceptions is sometimes blurred. However, the outcome is identical: failure of the claim against the agency.

\section{B.1 Legislative framework}

The issue of the scope of liability of public agencies in the United States is regulated both by federal and state legislation, as well as by state common law. At the rhetorical level at least, the point of departure in United States law reflects the aspiration to equate the status of tortfeasors in the public sector to that of those in the private sector. Thus, the doctrine of sovereign immunity was abolished back in 1946, and was replaced by the principle

liability on the agency under the circumstances described in the court judgment; analytical remarks. Attention is drawn to the fact that while the areas of activity in the various states discussed here are indeed similar, they are not identical due to the specific characteristics of adjudication prevalent in each of the different states. 
of equalization of status - according to which federal agencies would be obligated to pay compensation "in the same manner and to the same extent as a private individual under like circumstances". ${ }^{2}$ This - and in view of the clear wording of Section 2674 of the Liability of United States law - paved the way for filing tort claims against the government:

The United States shall be liable, respecting the provisions of this title relating to tort claims, in the same manner and to the same extent as a private individual under like circumstances, but shall not be liable for interest prior to judgment or for punitive damages. (Italics mine)

At the same time, to prevent the indefinite extension of government liability - and, along with it, a torrent of claims, over-deterrence, and disruption of ongoing government activity - the law on the equalization of status was accompanied both by the according of diverse immunities to federal agencies and by liability-limiting rules that were adopted and developed in court judgments, and on which I enlarge below. The list of statutory immunities is to be found in the provisions of Section 2680 of the Federal Code. These include both "specific provisions", which accord immunity to specific federal agencies, as well as "general provisions", which are not directed at a specific public agency and accord immunity with regard to specific types of activity.

Thus, Subsection (h) grants agencies extensive immunity from claims arising out of diverse torts, and determines that

Any claim arising out of assault, battery, false imprisonment, false arrest, malicious prosecution, abuse of process, libel, slander, misrepresentation, deceit, or interference with contract rights: Provided, That, with regard to acts or omissions of investigative or law enforcement officers of the United States Government, the provisions of this chapter and section $1346(\mathrm{~b})$ of this title shall apply to any claim arising, on or after the date of the enactment of this proviso, out of assault, battery, false imprisonment, false arrest, abuse of process, or malicious prosecution. For the purpose of this subsection, "investigative or law enforcement officer" means any officer of the United States who is empowered by law to execute searches, to seize evidence, or to make arrests for violations of Federal law.

Subsection (n) of the Federal Code also provides for the

\footnotetext{
2 The Federal Tort Claims Act (FTCA), 28 U.S.C. §§ 2674-2680 (hereinafter: the "Liability of United States law" or the "Federal Code"); see also the survey in D.B. Dobbs, The Law of Tort (2001).

${ }^{3}$ For the full list of immunities, see, as said, Section 2680 of the Liability of United States law; for an analysis of these provisions, see Dobbs, ibid., pp. 695-715.
}

immunity of federal agencies from claims filed against banks, determining that they are immune from "Any claim arising from the activities of a Federal land bank, a Federal intermediate credit bank, or a bank for cooperatives".

Moreover, the Federal Code provides for the immunity of federal agencies from claims arising out of fiscal and monetary activity (Subsection (i)), taxation activity (Subsection (c)), military activity in wartime (Subsection (j)), as well as activity in foreign countries (Subsection (k)).

In addition, the beginning of Subsection (a) provides for general immunity with regard to an act or omission arising from the execution of a statutory provision. Like the parallel protection in English law - on which I expand in the next part of this article - this provision is only applicable if the act or omission was made by the public agent while exercising due care. In other words, this immunity may apply when the public agent was not negligent in the execution of the statutory provision.

Finally, the main, important provision for immunity is to be found at the end of Section 2680(a) of the Liability of United States law. This provision excludes from liability the exercise of discretion, or failure thereof, in the performance of a function or duty, determining that

Any claim based upon an act or omission of an employee of the Government, exercising due care, in the execution of a statute or regulation, whether or not such statute or regulation be valid, or based upon the exercise or performance or the failure to exercise or perform a discretionary function or duty on the part of a federal agency or an employee of the Government, whether or not the discretion involved be abused. (Italics mine)

Below, in Part B.2 - which analyzes the scope of liability in United States court judgments - we learn that the range of reasonability accorded to the diverse types of government discretion in the United States is indeed extremely broad. A provisional summary reveals that the principle of the equalization of status is qualified in the United States by means of diverse immunity provisions that considerably limit the scope of liability of federal agencies. ${ }^{3}$

With regard to the state level, the principles of liability and its conditions in most states are very similar to those applicable to federal agencies. In most states where state immunity was abolished, many limitations to the imposition of tort liability were preserved. ${ }^{4}$ Thirty states adopted the structure of the federal arrangement, abolishing the doctrine of sovereign immunity while providing for exceptions to state liability; sixteen states

\footnotetext{
${ }^{4}$ For an overview of the situation in the various states, see Dobbs, ibid., ibid.; L. Rosenthal, A Theory of Governmental Damages Liability: Torts, Constitutional Torts, and Takings, 9 U. Pa.J. Const. L. 797 (2007).
} 
adopted a contrary approach, namely, they left the arrangement with regard to general immunity untouched, but provided for exceptions where the state was not immune; three states went so far as to leave the sweeping overall immunity arrangement as is; and only one state, Washington, adopted a general liability arrangement without provisions for immunity. ${ }^{5}$

So, it transpires that the liability structure in the majority of the states of the United States is similar to the arrangement at the federal level: adoption of the principle of equalization of status, qualified by means of both statutory immunities and of liability-limiting rules that were adopted and developed by court judgments (to be enlarged on below, in Parts B.2 and B.3). In most states, 33 in number, a discretionary exception was adopted as one of the immunities available to them. ${ }^{6}$ Thus, the overall picture at the state level, too, is of widescale immunity from tort claims.

In the discussion, in Part B.2, on the liability of public agencies in United States court judgments, we shall see that in several states, local public agencies also enjoy statutory immunities to an extent similar to that of federal agencies and that, at the municipal level, too, tort liability is limited both by means of statutory immunities (mainly for actions of a governmental nature), as well as by means of liabilitylimiting doctrines. ${ }^{7}$

With regard to the personal tort liability of public agents in United States law, they originally did not enjoy immunity from tort claims arising from their deeds in the course of executing their government position. The judgment harbingering the change occurred in the Barr v. Matteo case, ${ }^{8}$ which held that federal agency officials, whether senior or junior, were immune from claims arising from torts committed while performing their government position. The rhetoric employed in the judgment is liability-limiting, and implies that this immunity applies independently of the motives leading to the tortious act and, hence, at least prima facie, also to acts committed with deliberate intention to cause harm. In this manner, the

\footnotetext{
${ }^{5}$ For a specific discussion on the State of Washington, see D.L. Stephens \& B.P. Harnetiaux, The Value of Government Tort Liability: Washington's State Journey from Immunity to Accountability, 30 Seattle U.L. Rev. 35.

${ }^{6}$ See discussion in Dobbs, ibid., Footnote 2, pp. 720-723.

${ }^{7}$ Ibid., pp. 718-732.

${ }^{8}$ Barr v. Matteo, 360 U.S. 564, 79 S. Ct. 1335 (1959).

${ }^{9}$ Although the scope of the protection emerging from the Barr case is wide, it appears nevertheless that its boundaries are narrow in two senses. First, it relates to agents exercising discretion. Second, this doctrine was qualified with respect to constitutional torts. Put differently, harm rendered to rights anchored in the Constitution is not immune, unless the said agents acted in good faith and in the belief that their tortious act was within their powers. See, for example, Bivens v. Six Unknown Named Agents of Federal Bureau of Narcotics, 403 U.S. 388 (1971).
}

scope of the protection enjoyed by public agencies was broadened to cover agents, whether department heads or their subordinates. ${ }^{9}$

Only in 1988 did the United States lawmaker regulate the immunity of federal agency employees in the framework of the Federal Employees Liability Reform and Tort Compensation Act. ${ }^{10}$ The Employee Immunity Act extends protection to agency employees by instructing that when a tort claim is filed against them, they are to be replaced by the United States, which will be the defendant in the statement of claims. ${ }^{11}$ So, the Act in fact extends absolute protection to federal employees, and instructs that they be replaced as defendant by the government in all cases, in spite of the claim being filed against them for an act executed by them in the course of the execution of their government position. ${ }^{12}$

A provisional summary reveals that the protection accorded by United States law to federal employees is extensive, as in these central aspects: one, it is not limited solely to employees filling a government role; second, at least in its wording, it is also applicable when the agency worker acts with flippancy, even with the intention of causing harm. As for the states, we saw that only one, Washington, adopted a general arrangement of liability without provisions for immunity. With that exception, all the others enacted laws limiting, in one way or the other, the government's tort liability, much like the Liability of United States law that applies at the federal level. These laws usually also limit the liability of agency workers, so that at the state level, too, they enjoy extensive protection. In addition, in many states local government is perceived as part of state government and, consequently, the rules applying to government workers apply as a matter of course to local government workers.

It transpires from the aforesaid that the lawmaker in the United States provided the courts with diverse legal instruments to maintain a regime of cautious, limited government liability at all its levels. Now, the questions to be clarified are the position of the courts in the United

${ }^{10}$ Federal Employees Liability Reform and Tort Compensation Act 28 U.S.C \$2679 (hereinafter: the "Employee Immunity Act").

11 It is to be noted that the United States Congress passed this act in response to the decision of the Supreme Court, which limited the absolute immunity of federal officials to situations where their actions were "within the outer perimeter of an official's duties and... discretionary in nature". See, also, Westfall v. Erwin, 484 U.S. 292 (1988).

12 This procedure is possible when the United States Attorney's Office confirms that such-and-such a government employee is being sued in the course of performing their work. Both employee and claimant are authorized to object to the granting of, or failure to grant, such a clearance and to appeal to the court to adjudicate the issue. 
States on this issue and whether they indeed utilize these instruments. As we shall see shortly, they accord considerable weight to these statutory immunities and to liability-limiting considerations. It also seems that the discretionary exception is the major legal instrument by means of which United States court judgments limit the scope of the tort liability of public agencies. As the discussion below demonstrates, the main obstacle facing a potential injured party suing a public agency in the United States is to convince the court that the activity of that agency does not enjoy the protection of the discretionary exception. We shall see that although at times such tort claims were indeed successful - for example for negligence in the supervision of the manufacture of a vaccination and for negligence in the supervision and maintenance of a maritime lighthouse which failed to function - in most cases claimants find it impossible to overcome this hurdle.

B.2 United States court judgments
In an attempt to trace the logic behind the prominent decisions of the courts in the United States, I decided to analyze them in this subpart according to five areas of activity of the modern state: maintenance of the stability of financial institutions; infrastructure; security and emergency services; goods and services; regulation, supervision and licensing. We will see that this fine, precise analysis is capable of providing many answers with regard to the approach adopted in United States court judgments. It can be generalized, already at this stage, that my fundamental conclusion in this subpart will be that the traditional liability-limiting approach is extremely prominent in the United States. The analysis hereinafter will demonstrate that this traditional approach is implemented in all areas of state activity. So, the tables presented below will allow the reader to get a reliable picture of the extent of the protections enjoyed by public agencies in United States court judgments and, in particular, of the latitude of discretionary protection.

(a) Maintenance of the Stability of Financial Institutions

\begin{tabular}{|c|c|c|c|c|c|c|c|}
\hline & Case Name & $\begin{array}{c}\text { Alleged } \\
\text { Government } \\
\text { Negligence }\end{array}$ & $\begin{array}{c}\text { Was } \\
\text { Liability } \\
\text { Imposed }\end{array}$ & $\begin{array}{l}\text { Type of } \\
\text { Harm }\end{array}$ & $\begin{array}{c}\text { Act / } \\
\text { Omission }\end{array}$ & $\begin{array}{c}\text { Direct / } \\
\text { Indirect } \\
\text { Tortfeasor }\end{array}$ & Remarks \\
\hline 1. & $\begin{array}{l}\text { Starr } \\
\text { International } \\
\text { Company v. } \\
\text { Federal } \\
\text { Reserve } \\
\text { Bank of New } \\
\text { York }^{13}\end{array}$ & $\begin{array}{l}\text { The injured party, } \\
\text { who was a } \\
\text { company } \\
\text { shareholder, } \\
\text { contended that the } \\
\text { omissions of the } \\
\text { Federal Reserve } \\
\text { Bank of New York } \\
\text { constituted a } \\
\text { breach of its } \\
\text { pledges to } \\
\text { company } \\
\text { shareholders and } \\
\text { hence was liable } \\
\text { for their losses. }\end{array}$ & No & $\begin{array}{c}\text { Economic } \\
\text { loss }\end{array}$ & Omission & $\begin{array}{c}\text { Indirect } \\
\text { tortfeasor }\end{array}$ & $\begin{array}{l}\text { The court rejected the claim, relying } \\
\text { on the discretionary exception. } \\
\text { According to the court judgment, the } \\
\text { purpose of this exception was to } \\
\text { prevent interference by judicial } \\
\text { proceedings in administrative } \\
\text { decisions based on social, financial } \\
\text { and policy considerations. } \\
\text { Furthermore, the court opined that } \\
\text { agencies are to be exempted from } \\
\text { liability in such cases, in order to } \\
\text { allow them to operate without fear of } \\
\text { tort claims. }\end{array}$ \\
\hline 2. & $\begin{array}{l}\text { United States } \\
\text { v. Gaubert }\end{array}$ & $\begin{array}{l}\text { Omission on the } \\
\text { part of the federal } \\
\text { agency in } \\
\text { monitoring a } \\
\text { savings and loan } \\
\text { association. }\end{array}$ & No & $\begin{array}{c}\text { Economic } \\
\text { loss }\end{array}$ & Omission & $\begin{array}{l}\text { Indirect } \\
\text { tortfeasor }\end{array}$ & $\begin{array}{l}\text { The claim was rejected, relying on } \\
\text { the discretionary exception. The } \\
\text { claim was filed by a shareholder } \\
\text { alleging economic loss due to } \\
\text { negligent government supervision of } \\
\text { the association. The approach of the } \\
\text { Supreme Court of the United States } \\
\text { in this judgment with regard to } \\
\text { immunity was that the discretionary } \\
\text { exception shielded the regulator } \\
\text { when its acts included an element of } \\
\text { discretion or of choice between } \\
\text { several courses of action that were } \\
\text { based on considerations of public } \\
\text { policy. Put differently, the ability to } \\
\text { choose between a number of courses }\end{array}$ \\
\hline
\end{tabular}

${ }^{13}$ Starr Int'l Co. v. Fed. Reserve Bank of N.Y., 906 F. Supp. 2d $202 \quad$ United States v. Gaubert, 499 U.S 315 (1991). ${ }^{14}$ (2012). 


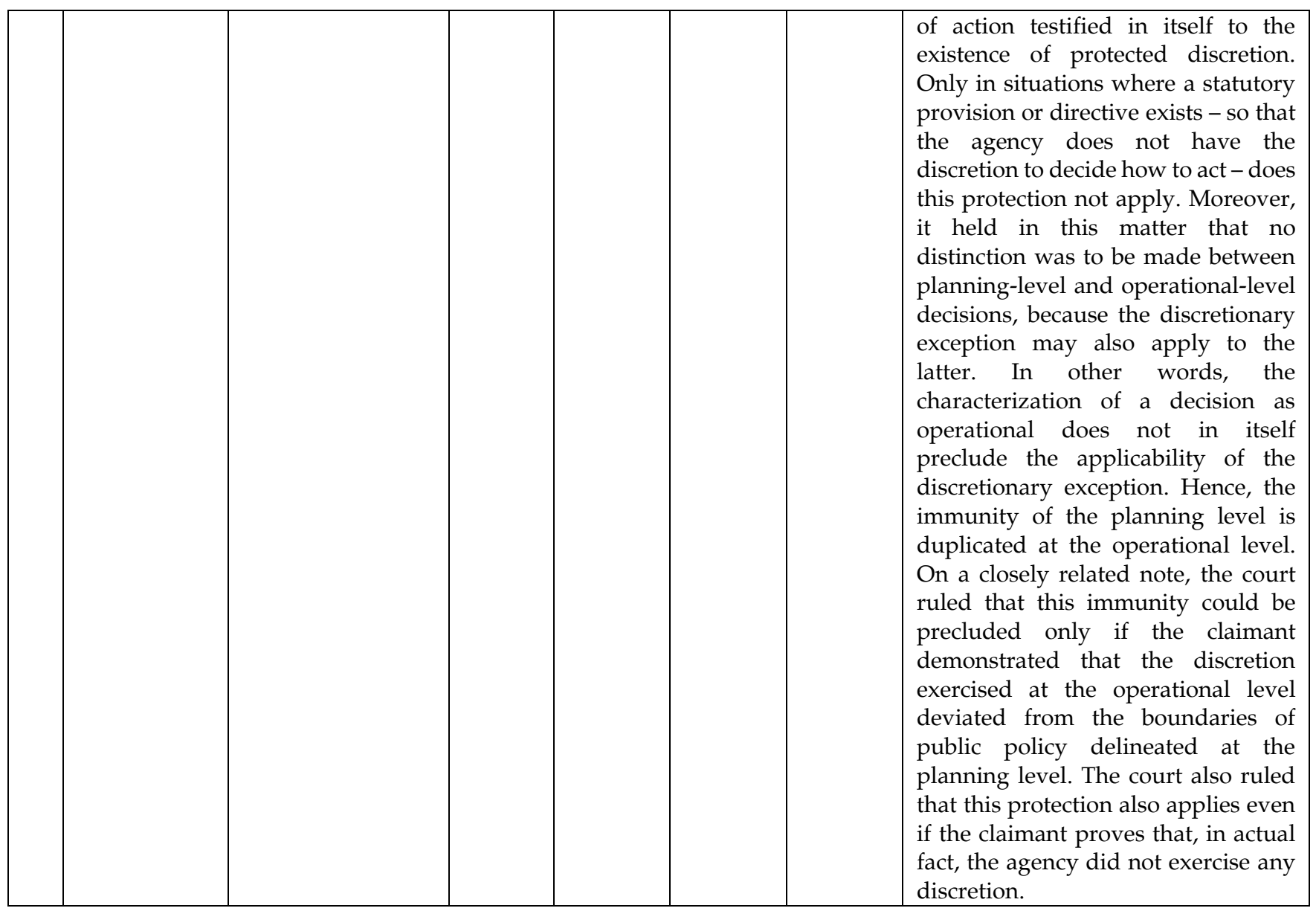

(b) Infrastructure

\begin{tabular}{|c|c|c|c|c|c|c|c|}
\hline & Case Name & $\begin{array}{c}\text { Alleged } \\
\text { Government } \\
\text { Negligence }\end{array}$ & $\begin{array}{c}\text { Was } \\
\text { Liability } \\
\text { Imposed }\end{array}$ & $\begin{array}{l}\text { Type of } \\
\text { Harm }\end{array}$ & $\begin{array}{c}\text { Act / } \\
\text { Omission }\end{array}$ & $\begin{array}{c}\text { Direct / } \\
\text { Indirect } \\
\text { Tortfeasor }\end{array}$ & Remarks \\
\hline 1. & $\begin{array}{l}\text { Baum v. } \\
\text { United } \\
\text { States }^{15}\end{array}$ & $\begin{array}{l}\text { Use of unsuitable } \\
\text { material in the } \\
\text { construction of a } \\
\text { bridge and safety } \\
\text { railing. The } \\
\text { claimants alleged } \\
\text { the existence of } \\
\text { negligence in the } \\
\text { planning, } \\
\text { construction and } \\
\text { maintenance } \\
\text { stages of the } \\
\text { bridge and railing. }\end{array}$ & No & $\begin{array}{l}\text { Mainly } \\
\text { physical } \\
\text { harm }\end{array}$ & Act & $\begin{array}{c}\text { Direct } \\
\text { tortfeasor }\end{array}$ & $\begin{array}{l}\text { Although it was a matter of physical } \\
\text { harm - the agency being a direct } \\
\text { tortfeasor that caused harm by its } \\
\text { act - liability was not imposed. The } \\
\text { court ruled that the decision of the } \\
\text { agency in these matters entailed the } \\
\text { taking into account of financial and } \\
\text { public policy considerations that } \\
\text { Congress sought to protect. }\end{array}$ \\
\hline 2. & $\begin{array}{l}\text { Hawes v. } \\
\text { United } \\
\text { States }^{16}\end{array}$ & $\begin{array}{l}\text { Negligent } \\
\text { maintenance of an } \\
\text { obstacle course at } \\
\text { an army base. }\end{array}$ & No & $\begin{array}{c}\text { Physical } \\
\text { harm }\end{array}$ & Omission & $\begin{array}{c}\text { Direct } \\
\text { tortfeasor }\end{array}$ & $\begin{array}{l}\text { The claim was rejected, relying on } \\
\text { the discretionary exception, in spite } \\
\text { of the fact that the negligent } \\
\text { maintenance of the obstacle course } \\
\text { caused iron bars to fall on the foot of } \\
\text { the injured party, and to an } \\
\text { irreversibly shattered femur. }\end{array}$ \\
\hline 3. & Rosebush v. & Negligence in & No & Physical & Act & Direct & Liability was precluded on the \\
\hline
\end{tabular}

${ }^{15}$ Baum v. United States, 986 F.2d 716 (4 $4^{\text {th }}$ Cir. 1993).

Hawes v. United States, 409 F.3d 213 ( $4^{\text {th }}$ Cir. 2005). ${ }^{16}$ 


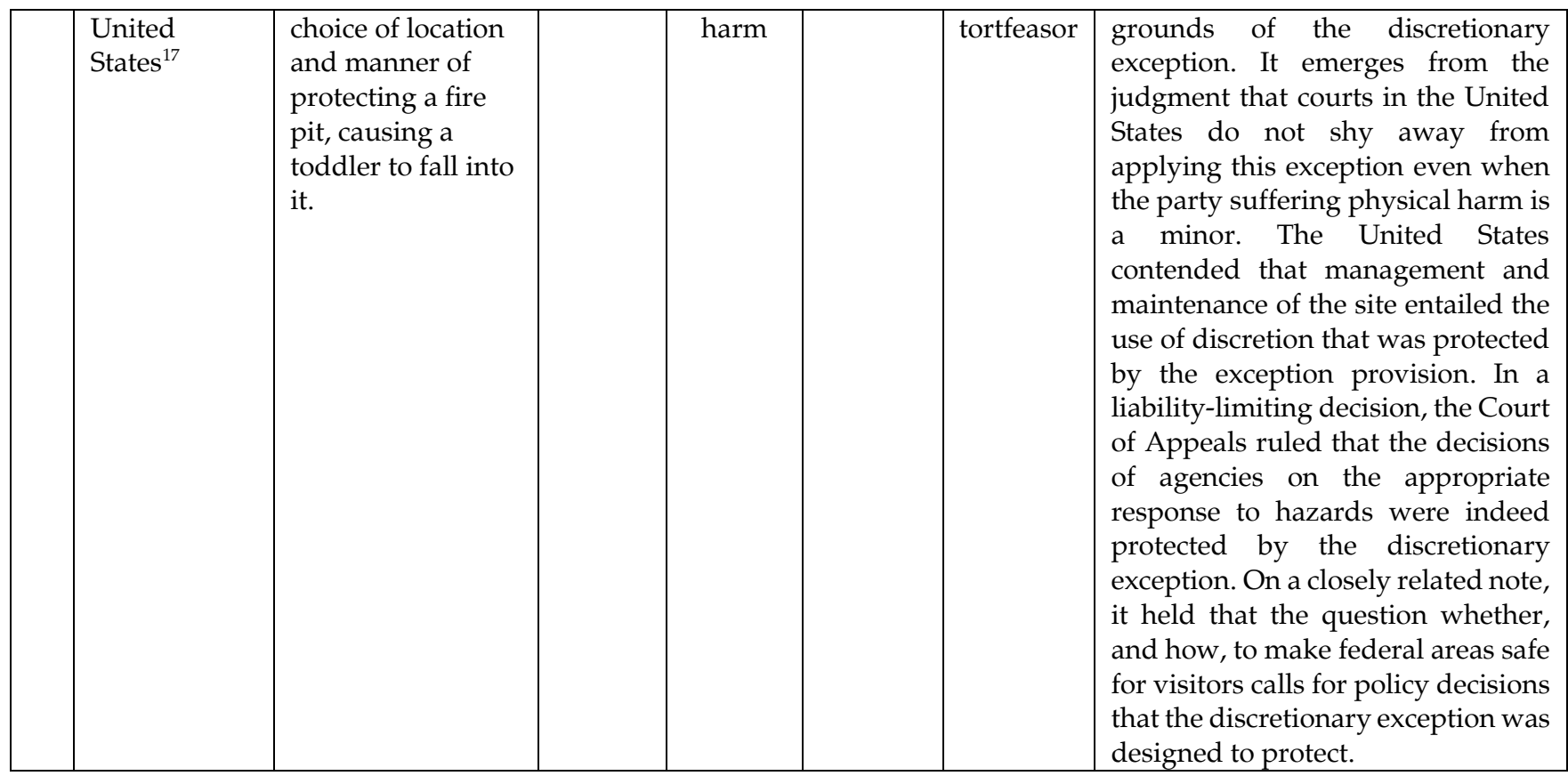

(c) Security and Emergency Services

\begin{tabular}{|c|c|c|c|c|c|c|c|}
\hline & Case Name & $\begin{array}{l}\text { Alleged Government } \\
\text { Negligence }\end{array}$ & $\begin{array}{l}\text { Was } \\
\text { Liability } \\
\text { Imposed }\end{array}$ & $\begin{array}{l}\text { Type of } \\
\text { Harm }\end{array}$ & $\begin{array}{l}\text { Act / } \\
\text { Omissi } \\
\text { on }\end{array}$ & \begin{tabular}{|c|} 
Direct / \\
Indirect \\
Tortfeasor
\end{tabular} & Remarks \\
\hline 1. & $\begin{array}{l}\text { Cuffy v. City } \\
\text { of New } \\
\text { York }^{18}\end{array}$ & $\begin{array}{l}\text { Failure of police } \\
\text { department to } \\
\text { implement an order of } \\
\text { protection against a } \\
\text { husband who verbally } \\
\text { and physically abused } \\
\text { his wife. The police } \\
\text { department even } \\
\text { briefed the claimant } \\
\text { that her husband was } \\
\text { under arrest and that, } \\
\text { consequently, she had } \\
\text { no reason to fear for her } \\
\text { safety. Two days later, } \\
\text { when she went to pick } \\
\text { up her son from school, } \\
\text { her husband } \\
\text { approached her and } \\
\text { stabbed her in the back. }\end{array}$ & No & $\begin{array}{c}\text { Physical } \\
\text { harm }\end{array}$ & $\begin{array}{c}\text { Omissi } \\
\text { on }\end{array}$ & \begin{tabular}{c|} 
Indirect \\
tortfeasor
\end{tabular} & $\begin{array}{l}\text { The court judgment elaborated on the } \\
\text { fact that the duty of the police } \\
\text { department to adopt reasonable care } \\
\text { could be inferred from the existence of } \\
\text { a special relationship of proximity } \\
\text { between it and the crime victim. } \\
\text { Accordingly, it devised a four-stage } \\
\text { test to determine whether this special } \\
\text { relationship existed: the assumption } \\
\text { of the injured party that the police } \\
\text { department, by means of promises or } \\
\text { acts, intended to act; knowledge of the } \\
\text { police department that inaction on its } \\
\text { part was liable to lead to the harm; a } \\
\text { direct relationship between the police } \\
\text { department and the injured party; } \\
\text { and, finally, reliance of the crime } \\
\text { victim on the commitment of the } \\
\text { police department to act to eliminate } \\
\text { the threat to the former. In this case, } \\
\text { the New York Court of Appeals ruled } \\
\text { that the element of reliance was not } \\
\text { met and, therefore, rejected the claim } \\
\text { against the police department. }\end{array}$ \\
\hline 2. & $\begin{array}{l}\text { Hernandez } \\
\text { v. City of } \\
\text { Pomona }^{19}\end{array}$ & $\begin{array}{l}\text { Failure to maintain } \\
\text { public order. }\end{array}$ & $\mathrm{No}$ & $\begin{array}{c}\text { Physical } \\
\text { harm }\end{array}$ & Act & $\begin{array}{c}\text { Direct } \\
\text { tortfeasor }\end{array}$ & $\begin{array}{l}\text { The court determined that the police } \\
\text { department was not liable for the } \\
\text { negligent killing of a man on the run } \\
\text { while chasing him. This case clarifies }\end{array}$ \\
\hline
\end{tabular}

${ }^{17}$ Rosebush v. United States, 119 F.3d 438, 443 (6 ${ }^{\text {th }}$ Cir. 1997).

${ }^{18}$ Cuffy v. City of New York, 69 N.Y.2d 255, 260, 513 N.Y.S.2d 372, 505 N.E.2d 937 [1987].

Hernandez v. City of Pomona, 207 P.3d 506 (2009). ${ }^{19}$ 


\begin{tabular}{|c|c|c|c|c|c|c|c|}
\hline & & & & & & & $\begin{array}{l}\text { the cautious, traditional approach of } \\
\text { United States law - and the scope of } \\
\text { the protective shield extended over } \\
\text { the activity of public agencies } \\
\text { providing security and emergency } \\
\text { services - given that in this case it was } \\
\text { a clear matter of action at the } \\
\text { operational level. Nevertheless - and } \\
\text { in spite of the fact that the harm } \\
\text { caused by the act of the public agency } \\
\text { as a direct tortfeasor was physical } \\
\text { harm-liability was not imposed. }\end{array}$ \\
\hline 3. & $\begin{array}{l}\text { Montez v. } \\
\text { United } \\
\text { States }^{20}\end{array}$ & $\begin{array}{l}\text { Negligence in watching } \\
\text { over a prisoner under } \\
\text { threat who was found } \\
\text { dead in his cell in } \\
\text { prison after being } \\
\text { beaten to death with a } \\
\text { fire extinguisher. }\end{array}$ & No & $\begin{array}{c}\text { Physical } \\
\text { harm }\end{array}$ & $\begin{array}{c}\text { Omissi } \\
\text { on }\end{array}$ & \begin{tabular}{|c|} 
Indirect \\
tortfeasor
\end{tabular} & $\begin{array}{l}\text { The claim was rejected on the grounds } \\
\text { of the discretionary exception. The } \\
\text { Court of Appeals determined that the } \\
\text { test of its applicability was twofold. } \\
\text { First, the court must clarify whether } \\
\text { the act in question entailed an element } \\
\text { of discretion or choice between a } \\
\text { numbers of possible courses of action. } \\
\text { If the answer was positive, as in this } \\
\text { matter, then the court must clarify } \\
\text { whether it was of the kind that the } \\
\text { discretionary exception was designed } \\
\text { to protect. The court ruled that the } \\
\text { answer to this question, too, was } \\
\text { positive. }\end{array}$ \\
\hline 4. & $\begin{array}{l}\text { Motyka v. } \\
\text { City of } \\
\text { Amsterdam }{ }^{21}\end{array}$ & $\begin{array}{l}\text { Liability of the security } \\
\text { and emergency services } \\
\text { in a case of failure to } \\
\text { respond to a citizen's } \\
\text { call for help. }\end{array}$ & No & $\begin{array}{c}\text { Mainly } \\
\text { physical } \\
\text { harm }\end{array}$ & $\begin{array}{c}\text { Omissi } \\
\text { on }\end{array}$ & $\begin{array}{c}\text { Indirect } \\
\text { tortfeasor }\end{array}$ & $\begin{array}{l}\text { The court ruled that agencies were not } \\
\text { obligated to respond to emergency } \\
\text { calls from citizens and, as a result, } \\
\text { could not be held liable even when the } \\
\text { person who called for help was } \\
\text { ultimately injured. The judgment } \\
\text { invoked the requirement of the } \\
\text { existence of a special relationship of } \\
\text { proximity between the agency and the } \\
\text { injured party, and determined that in } \\
\text { the cases included in this area of } \\
\text { agency activity, that proximity and } \\
\text { that special relationship required in } \\
\text { order to impose tort liability did not } \\
\text { exist. }\end{array}$ \\
\hline 5. & $\begin{array}{l}\text { Tippett v. } \\
\text { United } \\
\text { States }^{22}\end{array}$ & $\begin{array}{l}\text { Supervision by agency } \\
\text { of events within its } \\
\text { jurisdiction, including } \\
\text { keeping park visitors a } \\
\text { safe distance from } \\
\text { dangerous animals. }\end{array}$ & No & $\begin{array}{c}\text { Physical } \\
\text { harm }\end{array}$ & $\begin{array}{c}\text { Omissi } \\
\text { on }\end{array}$ & $\begin{array}{c}\text { Direct } \\
\text { tortfeasor }\end{array}$ & $\begin{array}{l}\text { The claim was rejected, relying on the } \\
\text { discretionary exception. The injured } \\
\text { parties contended that in light of a } \\
\text { security policy being in place in the } \\
\text { park, the park workers, who were } \\
\text { agency employees, did not have broad } \\
\text { discretion as to the handling of the } \\
\text { situation they came up against. The } \\
\text { court rejected this argument, thus } \\
\text { blurring the boundary between } \\
\text { planning and execution, and limiting } \\
\text { even further the areas of liability of the } \\
\text { United States. }\end{array}$ \\
\hline 6. & Town of & Claim filed by a wife on & No & Physical & Omissi & Indirect & The Supreme Court of the United \\
\hline
\end{tabular}

\footnotetext{
${ }^{20}$ Montez v. United States, 359 F.3d 392 (6 ${ }^{\text {th }}$ Cir. 2004).

${ }^{21}$ Motyka v. City of Amsterdam, 15 N.Y.2d 134 (1965).

${ }^{22}$ Tippett v. United States, 108 F.3d 1194 (10 $0^{\text {th }}$ Cir. 1997).
} 


\begin{tabular}{|c|c|c|c|c|c|c|c|}
\hline & $\begin{array}{l}\text { Castle Rock, } \\
\text { Colorado v. } \\
\text { Gonzales }^{23}\end{array}$ & $\begin{array}{l}\text { whose behalf an order } \\
\text { of protection was issued } \\
\text { against her separated } \\
\text { husband, forbidding } \\
\text { him to approach her or } \\
\text { their three daughters, } \\
\text { and even containing } \\
\text { police instructions on } \\
\text { how to abide by it. } \\
\text { When, contrary to the } \\
\text { order, the husband took } \\
\text { their three daughters } \\
\text { into his custody, the } \\
\text { wife turned several } \\
\text { times to the police } \\
\text { department to enforce } \\
\text { it, but to no avail. The } \\
\text { event ended in the } \\
\text { father murdering the } \\
\text { three daughters, } \\
\text { opening fire at the } \\
\text { police station, and } \\
\text { being shot dead. }\end{array}$ & & harm & on & tortfeasor & $\begin{array}{l}\text { States, overturning the judgment } \\
\text { handed down by the Federal Court of } \\
\text { Appeals, rejected the claim filed by } \\
\text { the wife, ruling that while the order of } \\
\text { protection indeed authorized the } \\
\text { police department to arrest the } \\
\text { husband, and even required it to do } \\
\text { so, that did not create an absolute duty } \\
\text { capable of leading to the conclusion } \\
\text { that failure on the part of the police } \\
\text { department to arrest the husband } \\
\text { constituted a breach warranting the } \\
\text { award of compensation to the wife. } \\
\text { The court judgment even elaborated } \\
\text { on the need to protect police } \\
\text { discretion in spite of the } \\
\text { circumstances that, on the face of } \\
\text { things, sufficed to limit it. }\end{array}$ \\
\hline 7. & $\begin{array}{l}\text { White v. } \\
\text { Beasley }^{24}\end{array}$ & $\begin{array}{l}\text { Failure of the police } \\
\text { department, which } \\
\text { received a call for help, } \\
\text { to prevent the murder } \\
\text { of a woman by her } \\
\text { husband. }\end{array}$ & No & $\begin{array}{c}\text { Physical } \\
\text { harm }\end{array}$ & $\begin{array}{c}\text { Omissi } \\
\text { on }\end{array}$ & $\begin{array}{c}\text { Indirect } \\
\text { tortfeasor }\end{array}$ & $\begin{array}{l}\text { In its judgment, the State of Michigan } \\
\text { Court of Claims noted that the public } \\
\text { duty doctrine applicable to law } \\
\text { enforcers protects them from tort } \\
\text { liability in such cases. }\end{array}$ \\
\hline
\end{tabular}

(d) Goods and Services

\begin{tabular}{|c|c|c|c|c|c|c|c|}
\hline & Case Name & \begin{tabular}{|c|} 
Alleged \\
Government \\
Negligence
\end{tabular} & $\begin{array}{c}\text { Was } \\
\text { Liability } \\
\text { Imposed }\end{array}$ & $\begin{array}{c}\text { Type of } \\
\text { Harm }\end{array}$ & $\begin{array}{c}\text { Act / } \\
\text { Omission }\end{array}$ & $\begin{array}{c}\text { Direct / } \\
\text { Indirect } \\
\text { Tortfeasor }\end{array}$ & Remarks \\
\hline 1. & $\begin{array}{l}\text { C.R.S. v. } \\
\text { United } \\
\text { State }^{25}\end{array}$ & $\begin{array}{c}\text { Administrati } \\
\text { on of HIV- } \\
\text { contaminate } \\
\text { d blood } \\
\text { infusion to } \\
\text { patient. }\end{array}$ & No & $\begin{array}{c}\text { Physical } \\
\text { harm }\end{array}$ & Act & $\begin{array}{c}\text { Direct } \\
\text { tortfeasor }\end{array}$ & $\begin{array}{l}\text { The court rejected the claim, citing the discretionary } \\
\text { exception. It held that protected decisions are } \\
\text { government decisions that are based on public, } \\
\text { social, financial and policy considerations. This } \\
\text { broad interpretation enabled the court to reject the } \\
\text { claimants' allegation of negligence on the part of the } \\
\text { agency by its failure to appropriately screen blood } \\
\text { donors and eliminate HIV-positive ones, in spite of } \\
\text { the physical harm caused. }\end{array}$ \\
\hline 2. & $\begin{array}{l}\text { Indian } \\
\text { Towing } \\
\text { Co v. } \\
\text { United } \\
\text { States }^{26}\end{array}$ & $\begin{array}{c}\text { Maintenance } \\
\text { of a maritime } \\
\text { lighthouse } \\
\text { whose light } \\
\text { went out. }\end{array}$ & Yes & $\begin{array}{c}\text { Physical } \\
\text { harm } \\
\text { and } \\
\text { property } \\
\text { damage }\end{array}$ & Act & $\begin{array}{c}\text { Direct } \\
\text { tortfeasor }\end{array}$ & $\begin{array}{l}\text { In this case, the Coast Guard maintained a } \\
\text { lighthouse negligently, leading to its light } \\
\text { extinguishing and a tugboat sinking after going off } \\
\text { course. The court ruled that the discretionary } \\
\text { exception applied at the planning level, but not at } \\
\text { the operational level. Since the maintenance and } \\
\text { operation of the lighthouse were classified as } \\
\text { actions at the operational level - to distinguish from } \\
\text { decisions whether at all to place a lighthouse and } \\
\text { what kind - liability was imposed on the agency. }\end{array}$ \\
\hline 3. & Smith v. & Negligenc & No & Physical & Omission & Direct & The court precluded liability, applying the \\
\hline
\end{tabular}

${ }^{23}$ Town of Castle Rock, Colorado v. Gonzales 545 U.S. 748 (2005).

${ }^{24}$ White v. Beasley 552 N.W. 2d 1 (1996).

${ }^{25}$ C.R.S. v. United States, $11 \mathrm{~F} 3 \mathrm{~d} 791\left(8^{\text {th }}\right.$ Cir. 1993).

Indian Towing Co v. United States, 350 U.S. 61 (1995). ${ }^{26}$ 


\begin{tabular}{|c|c|c|c|c|c|c|c|}
\hline & $\begin{array}{l}\text { Washingt } \\
\text { on } \\
\text { Metropol } \\
\text { itan Area } \\
\text { Transit } \\
\text { Authorit } \\
y^{27}\end{array}$ & $\begin{array}{l}\text { e by } \\
\text { agency in } \\
\text { manner of } \\
\text { operating } \\
\text { escalators. }\end{array}$ & & harm & & tortfeasor & $\begin{array}{l}\text { discretionary exception to the circumstances of this } \\
\text { case. It held that, in spite of the gravity of the } \\
\text { physical harm in question, the activity of the } \\
\text { WMATA employees with regard to the manner of } \\
\text { operating the escalators was characterized by } \\
\text { discretion deserving of protection. }\end{array}$ \\
\hline 4. & $\begin{array}{l}\text { United } \\
\text { States } \\
\text { Aviation } \\
\text { Underw } \\
\text { riters v. } \\
\text { United } \\
\text { States }^{28}\end{array}$ & $\begin{array}{l}\text { Damage } \\
\text { caused to } \\
\text { aircraft } \\
\text { due to } \\
\text { mistakes } \\
\text { of the } \\
\text { National } \\
\text { Weather } \\
\text { Service. }\end{array}$ & No & $\begin{array}{c}\text { Physical } \\
\text { harm } \\
\text { and } \\
\text { property } \\
\text { damage }\end{array}$ & Act & $\begin{array}{l}\text { Indirect } \\
\text { tortfeasor }\end{array}$ & $\begin{array}{l}\text { The claim was rejected on the grounds of the } \\
\text { discretionary exception. By chance, a plane crashed } \\
\text { due to air turbulence. The United States admitted } \\
\text { that once the National Weather Service forecasts the } \\
\text { formation of severe turbulence it no longer has } \\
\text { discretion and must provide this information to } \\
\text { pilots. At the same time, the United States } \\
\text { contended that the very act of forecasting } \\
\text { turbulence and determining its kind are acts of } \\
\text { discretion that fall within the boundaries of the } \\
\text { discretionary exception. The Court of Appeals ruled } \\
\text { that the assertion of the National Weather Service- } \\
\text { that the air turbulence formed did not require that } \\
\text { the pilots be issued with a warning - was immune } \\
\text { from liability under the discretionary exception. In } \\
\text { spite of the arguments against categorizing the } \\
\text { determination of the National Weather Service as a } \\
\text { policy decision, the Supreme Court left the } \\
\text { judgment in place. }\end{array}$ \\
\hline
\end{tabular}

(e) Regulation, Supervision and Licensing

\begin{tabular}{|c|c|c|c|c|c|c|c|}
\hline & $\begin{array}{l}\text { Case } \\
\text { Name }\end{array}$ & $\begin{array}{c}\text { Alleged } \\
\text { Government } \\
\text { Negligence }\end{array}$ & $\begin{array}{c}\text { Was } \\
\text { Liability } \\
\text { Imposed }\end{array}$ & $\begin{array}{c}\text { Type of } \\
\text { Harm }\end{array}$ & \begin{tabular}{|c|} 
Act $/$ \\
Omiss \\
ion
\end{tabular} & $\begin{array}{c}\text { Direct / } \\
\text { Indirect } \\
\text { Tortfeasor }\end{array}$ & Remarks \\
\hline 1. & $\begin{array}{l}\text { Berkovi } \\
\text { tz v. } \\
\text { United } \\
\text { States }^{29}\end{array}$ & $\begin{array}{l}\text { Supervision of } \\
\text { the } \\
\text { manufacture of } \\
\text { a vaccination. } \\
\text { The claim was } \\
\text { filed both } \\
\text { against the } \\
\text { agency, as the } \\
\text { regulatory } \\
\text { entity that } \\
\text { authorized the } \\
\text { manufacture of } \\
\text { the medicine, } \\
\text { as well as } \\
\text { against the } \\
\text { Food and Drug } \\
\text { Administratio } \\
n \text {, which } \\
\text { authorized the } \\
\text { marketing of } \\
\text { the shipment } \\
\text { of defective } \\
\text { medicine. }\end{array}$ & Yes & $\begin{array}{c}\text { Physical } \\
\text { harm }\end{array}$ & Act & $\begin{array}{l}\text { Indirect } \\
\text { tortfeasor }\end{array}$ & $\begin{array}{l}\text { In spite of the imposition of liability, the rhetoric in } \\
\text { the judgment is liability-limiting. In this case, } \\
\text { liability was imposed not because of a limitation of } \\
\text { the discretionary exception but rather because the } \\
\text { agency deviated from binding standards } \\
\text { determined by law and by internal regulations. In } \\
\text { this case, the agency employees did not exercise } \\
\text { discretion, and were not authorized to do so. Hence, } \\
\text { the discretionary exception was clearly not } \\
\text { applicable here. Moreover, the court stressed in its } \\
\text { judgment that the activity of the operational level } \\
\text { was also likely to enjoy the protection of the } \\
\text { exception clause, subject to the matter at hand } \\
\text { entailing policy decisions. }\end{array}$ \\
\hline
\end{tabular}

\footnotetext{
${ }^{27}$ Smith v. Washington Metropolitan Area Transit Auth., 290 F.3d 201 (4 ${ }^{\text {th }}$ Cir. 2002).

${ }^{28}$ United States Aviation Underwriters v. United States, 562 F.3d 1297 (11 ${ }^{\text {th }}$ Cir. 2009).

${ }^{29}$ Berkovitz v. United States, 486 U.S. 531 (1988).
} 


\begin{tabular}{|c|c|c|c|c|c|c|c|}
\hline 2. & $\begin{array}{l}\text { Connec } \\
\text { tion } \\
\text { Trainin } \\
\text { g } \\
\text { Service } \\
\text { S v. } \\
\text { City of } \\
\text { Philade } \\
\text { lphia }\end{array}$ & $\begin{array}{l}\text { Refusal by } \\
\text { agency to } \\
\text { grant business } \\
\text { licenses to } \\
\text { applicants. }\end{array}$ & No & $\begin{array}{c}\text { Economi } \\
\text { c loss }\end{array}$ & Act & $\begin{array}{c}\text { Direct } \\
\text { tortfeasor }\end{array}$ & $\begin{array}{l}\text { The court was reluctant to recognize the duty of care } \\
\text { when the harm caused was pure economic loss or } \\
\text { pure emotional harm. }\end{array}$ \\
\hline 3. & $\begin{array}{l}\text { Dalehit } \\
\text { e v. } \\
\text { United } \\
\text { States }^{31}\end{array}$ & $\begin{array}{l}\text { Government } \\
\text { oversight and } \\
\text { supervision of } \\
\text { the } \\
\text { manufacture } \\
\text { and marketing } \\
\text { of a chemical } \\
\text { fertilizer. }\end{array}$ & No & $\begin{array}{c}\text { Physical } \\
\text { harm }\end{array}$ & $\begin{array}{c}\text { Act } \\
\text { and } \\
\text { omissi } \\
\text { on }\end{array}$ & $\begin{array}{l}\text { Direct } \\
\text { tortfeasor }\end{array}$ & $\begin{array}{l}\text { The claim was rejected under the discretionary } \\
\text { exception, despite the fact that the explosion of the } \\
\text { chemical fertilizer, stored in the Port of Texas City, } \\
\text { caused } 560 \text { deaths and some } 3,000 \text { wounded, that } \\
\text { the damages claimed totaled } 200 \text { million dollars, } \\
\text { and that the United States was the direct tortfeasor. } \\
\text { The fertilizer was manufactured in a government } \\
\text { facility and was distributed in accordance with the } \\
\text { rules of the United States and under its supervision. } \\
\text { The court ruled that the decision to manufacture the } \\
\text { product, on the method to do so and on how to } \\
\text { handle it were made at the planning level and, } \\
\text { consequently, constituted an immune planning- } \\
\text { level decision. }\end{array}$ \\
\hline 4. & $\begin{array}{l}\text { Fisher } \\
\text { Bros. } \\
\text { Sales, } \\
\text { Inc v. } \\
\text { United } \\
\text { States }^{32}\end{array}$ & $\begin{array}{l}\text { Regulation of } \\
\text { food quality. }\end{array}$ & No & $\begin{array}{c}\text { Economi } \\
\text { c loss }\end{array}$ & Act & $\begin{array}{l}\text { Direct } \\
\text { tortfeasor }\end{array}$ & $\begin{array}{l}\text { The claim was rejected under the discretionary } \\
\text { exception, in spite of the fact that the refusal of the } \\
\text { Commissioner (the FDA) to grant a license to import } \\
\text { grapes was based on erroneous laboratory tests. An } \\
\text { approach emerges from the judgment that the very } \\
\text { decision to conduct the laboratory tests under such } \\
\text { circumstances may enjoy the protection of the } \\
\text { exception provision. To the crux of the case, the } \\
\text { court held that the discretionary exception was } \\
\text { designed to protect regulatory actions such as in the } \\
\text { case at hand. }\end{array}$ \\
\hline 5. & $\begin{array}{l}\text { United } \\
\text { States } \\
\text { v. S.A. } \\
\text { Empres } \\
\text { a de } \\
\text { Viacao } \\
\text { Aerea } \\
\text { Rio } \\
\text { Grande } \\
\text { nse }^{33}\end{array}$ & $\begin{array}{l}\text { Supervision of } \\
\text { compatibility } \\
\text { of airplanes } \\
\text { with required } \\
\text { safety } \\
\text { standards. } \\
\text { standards. }\end{array}$ & No & $\begin{array}{c}\text { Mainly } \\
\text { physical } \\
\text { harm }\end{array}$ & $\begin{array}{c}\text { Omiss } \\
\text { ion }\end{array}$ & $\begin{array}{l}\text { Indirect } \\
\text { tortfeasor }\end{array}$ & $\begin{array}{l}\text { In this case, the question of the negligence of the } \\
\text { Federal Aviation Administration (FDA), which } \\
\text { authorizes the use of commercial planes, was } \\
\text { deliberated. In the event in question, a number of } \\
\text { passengers met their deaths and others were injured } \\
\text { as a result of one plane crashing and another } \\
\text { catching fire. An examination conducted after the } \\
\text { event found that the FDA indeed supervised the } \\
\text { compatibility of the planes with required safety } \\
\text { standards, but only by means of spot checks. The } \\
\text { court rejected the claim against the agency, relying } \\
\text { on the discretionary exception, and ruled that } \\
\text { immune discretion is based on social, financial and } \\
\text { public policy considerations, as in the case at hand. } \\
\text { It also ruled that the answer to the question of the } \\
\text { applicability of the discretionary exception } \\
\text { depended on the type of decision, not on the rank of } \\
\text { the decision-maker. Consequently, the activity of } \\
\text { the operational level also enjoyed the protection of } \\
\text { the discretionary exception, provided it was a } \\
\text { matter of policy decisions. }\end{array}$ \\
\hline
\end{tabular}

Connection Training Services v. City of Philadelphia, 358 Fed. Appx 315 ( $3^{\text {rd }}$ Cir. 2009). ${ }^{30}$

${ }^{31}$ Dalehite v. United States, 347 U.S. 924 (1954).

${ }^{32}$ Fisher Bros. Sales, Inc v. United States, 46 F.3d 279 ( $3^{\text {rd }}$ Cir. 1995).

${ }^{33}$ United States v. S.A. Empresa de Viacao Aerea Rio Grandense (Varig Airlines), 467 U.S. 797 (1984). 


\section{B.3 Analysis and conclusions}

Twenty-one judgments were analyzed in Part B.2. Liability was not imposed on the agencies in $\mathbf{1 9}$ cases, that is, liability was only imposed in two cases. By means of the provisions of Section 2680(a), the Federal Code preserves sovereign immunity when it comes to discretionary functions or duties. And indeed, as emerges from the data in Part B.2, one of the most significant instruments for limiting the scope of liability of public agencies in the United States is the "discretionary exception".

In the Dalehite case, the decisions regarding the packaging method and its execution were categorized as immune decisions taking place at the planning level. This case clearly illustrates the scope of the protection of the discretionary exception from several aspects. First, this case did not concern an omission by the agency but, rather, an active hazard created by it. Second, it was a matter of severe, extensive personal injuries. Finally, it seems the case related to agency activity clearly lacking any governmental uniqueness in that it was a matter of the manufacture and marketing of a product similar to the activity of private manufacturers.

The distinction between cases necessitating the exercise of discretion at the planning level and between cases where it is a mere matter of execution is blurred, and United States courts frequently deliberated it. ${ }^{34}$ The Empresa case followed in the footsteps of the Dalehite case, further broadening the application of the discretionary exception in several aspects. First, in this case agency liability for severe, extensive personal injuries was unanimously precluded. Second, the rhetoric adopted in the judgment emphasizes the considerations for non-interference. And, thirdly, the judgment broadens the application of the discretionary exception to the operational level.

The Gaubert case adopted this path, too. As noted, a picture emerges from these judgments of widescale immunity. Subsequent judgments rendered in the United States - throughout the 1990s, in the Baum, C.R.S., Fisher, Rosebush, and Tippett cases, and throughout the 2000s, in the Smith, Montez, Hawes, and United States Aviation Underwriters cases - continued the trend of blurring the boundary between the planning and operational levels, expanding the boundaries of the discretionary exception further and further.

So, it transpires that the range of reasonability accorded by United States law to the various kinds of government discretion is exceedingly broad. By means of the discretionary exception, United States court judgments adopt a liability-limiting approach to public agencies with regard to their various areas of activity. As we saw in Part B.2 above, liability was precluded when agencies caused either economic loss or property damage, and even when they caused extensive physical harm. Liability was precluded both when the omissions of the agency caused the harm and also when it was caused by their active deeds. The discretionary exception was applied both when the agency was an indirect tortfeasor, and even when it was a direct tortfeasor. Furthermore, we saw that the agency was precluded from liability both when the inured party was an adult and also when it was a minor (who even suffered physical harm).

Moreover, the liability-limiting approach of the courts in the United States - in particular with regard to state and municipal levels - is reflected in additional liabilitylimiting instruments over and above the discretionary exception provision. One of the most important instruments the courts had recourse to - and we will expand further on this below, in the discussion on English law - was the requirement of a special affinity between the public agency and the injured party, and the determination that that affinity or special relationship of proximity between the two parties, required in order to impose tort liability, did not exist. Hence, liability was precluded in these cases due to the generality of the duty of the agency and due to its being a public duty that was not intended for the specific benefit of the injured party as an individual, but rather for the benefit of the public as a collective. As the analysis of United States court judgments revealed, the main benefactors of this liability-limiting doctrine are agencies providing security and emergency services. The courts in the United States refrain from determining the existence of general liability towards the public with regard to harm occurring as the result of failure on the part of agencies to provide appropriate police or fire extinguishing services. These agency duties are perceived, as said, as duties to the public as a collective, not as duties to the private individual. Thus, in a series of judgments dealing with the issue of failure to prevent crime, as in the Hernandez and Motyka cases, the courts determined that the emergency services are not obligated to respond to emergency calls by citizens, and tort liability was not imposed on them, even if the person calling for help was ultimately harmed.

Another liability-limiting instrument is related to the type of harm. We will refer to this liability-limiting instrument in the discussion on English law. However, we saw that a cautious, traditional approach to the imposition of liability for pure economic loss or pure emotional harm caused by agencies is also reflected in United States law. Put differently, United States law is loath to recognize the existence of the duty of care in cases involving pure

L.W. Prosser and W.P. Keeton on Torts ( $5^{\text {th }}$ ed., West Group, 1984).

\footnotetext{
${ }^{34}$ For a comprehensive overview and in-depth discussion of the question as to when the matter at hand is an action at the planning level or whether it is a mere matter of execution, see
} 
economic loss ${ }^{35}$ or pure emotional harm. ${ }^{36}$ This approach, which is implemented in various states to varying degrees, is indeed not specific to public agencies. However, it is capable of strongly influencing their scope of liability. Accordingly, the refusal by the commissioner to grant business licenses, as in the Connection Training Services case (a refusal that caused pure economic loss to the applicants), did not lead to the imposition of liability on the agency. Similarly, claims filed against the agency, for "educational negligence" that caused emotional harm, were sometimes rejected.

To conclude our discussion, it should also be stressed that the two judgments where liability was indeed imposed on the agencies do not constitute liability-expanding judgments. I will explain. It will be recalled that in the Indian Towing case, the decisions regarding the manner of maintaining the lighthouse were categorized as operational decisions that are exposed to liability. It appears this cannot be perceived as an expansion of the operational level that is exposed to liability, because in this case it was the agency that created a representation that a lighthouse was in place that lit the way for the tugboats. The injured parties relied on this representation plausibly, and suffered harm for so doing. So, liability was imposed on the agency not because of its pure omission but, rather, because of an active representation that created a considerable hazard of physical harm and property damage. As for the Berkovitz case, as recalled it dealt with the negligence of public agencies in supervising a vaccination administered to the claimant against polio and who contracted the disease as a result. The claim was filed both against the agency that authorized the manufacture of the medicine as well as against the Food and Drug Administration, which authorized the marketing of the defective shipment. Attention is drawn to the fact that in this case, liability was not imposed due to the limitation of the discretionary exception provision but, rather, because the agency deviated from binding standards determined by law and in the internal regulations. The agency employees did not exercise discretion in this case, and were not authorized to do so. So, the discretionary exception certainly is not applicable here. In the spirit of the Varig

${ }^{35}$ Restatement (Third) of Torts: Economic Torts and Related Wrongs, Part 2, Ch. 3 (Draft No. 2, 2006). The draft of the Third Restatement, relating to economic torts, imposes many limitations on the scope of liability of tortfeasors for misrepresentations made by them. As noted, when it is a matter of pure economic loss sustained by an indirectly injured party, the "rule of exclusion" prevails, according to which the injured party is not entitled to compensation for the tort of negligence under this head of tort, barring exceptional cases.

${ }^{36}$ Restatement (Third) of Torts: Liability for Physical Harm and Emotional Harm (Draft No. 5, 2007). The draft adopts a cautious, limiting approach to this head of tort, and mentions the various considerations for limiting liability for it, including concern about frivolous claims and courts being overwhelmed by a torrent of claims. In everything concerning directly injured parties, the draft distinguishes between pure emotional harm
Airlines case, and grounding itself on it, the court once again stressed in its judgment that the activity of the operational level, too, may enjoy the protection of the discretionary exception, subject to it being a matter of policy decisions. So, this judgment, too, preserves the broad applicability of the discretionary exception, and does not reduce it compared with previous judgments.

To summarize this part, it emerges that the scope of tort liability of public agencies in the United States is very limited, both on the strength of statutory immunities as well as of liability-limiting instruments. Diverse policy considerations underly this approach, including concern about harming the principle of the separation of powers, over-deterrence of agencies, the unleashing of a torrent of claims, including frivolous ones, and disruption of ongoing government activity. In view of this, it can be assessed that judicial criticism of public agencies by means of tort law has no significant effect, and that United States law accords considerable weight, possibly too much weight, to liability-limiting considerations.

\section{Part C: Tort Law and Public Authorities in ENGLAND}

The courts in England also struggle with the question of delineating the boundaries of the tort liability of public authorities. As we will now see, in England, too, the remnants of the traditional doctrine, upholding the principle of sovereign immunity, are conspicuous in many cases. This approach stems from concern about overdeterrence of public authorities, the unleashing of a torrent of claims, including frivolous ones, disruption of ongoing government activity, and harm being caused to the principle of the separation of powers. At the same time, this liability-limiting approach is not as polarized as what we saw in United States law - which extends a very wide, tight protective net over the different areas of government discretion. So, the conclusion arising from this part will be that the liability-limiting doctrine is implemented to some

caused by the intentional conduct of the tortfeasor and between pure emotional harm caused by negligence on its part. The tendency with regard to the latter is not to recognize the existence of a duty. Limitation of the scope of liability is mainly done by means of the twofold requirement - the existence of significant severe emotional harm and the existence of a special relationship of proximity between the tortfeasor and the injured party. With respect to indirectly injured parties, liability for this head of tort is limited even further, since here the requirement is threefold - the existence of significant severe pure emotional harm, the existence of a special relationship of proximity between the indirectly injured party and the directly injured party, and the existence of a causal relationship characterized by restrictive requirements. 
extent in England by means of diverse judicial instruments. $^{37}$

\section{C.1 Legislative framework}

The tort liability of public authorities is precluded in England by means of both government legislation and international arrangements. Until 1947, public authorities in England enjoyed broad immunity from tort claims. It was only after World War Two that English law abandoned the perception that "The King can do no harm", ${ }^{38}$ and defined the liability of the Crown in tort as the same as that of any private person, thus:

Liability of the Crown in tort.

(1)Subject to the provisions of this Act, the Crown shall be subject to all those liabilities in tort to which, if it were a private person of full age and capacity, it would be subject:-

(a) in respect of torts committed by its servants or agents; (b) in respect of any breach of those duties which a person owes to his servants or agents at common law by reason of being their employer; and (c) in respect of any breach of the duties attaching at common law to the ownership, occupation, possession or control of property... ${ }^{39}$

As we saw in Part B above with respect to United States law, the law in England, too, accords protection to public authorities for actions executed by virtue of statutory provisions. However, this protection is only available to them if they acted reasonably, the premise being that statutory provisions do not authorize public authorities to act unreasonably, unless they explicitly determine this. Hence, it emerges that the protection afforded to actions by virtue of statutory provisions does not apply to situations involving negligence in the performance of the duty and, as a result, its applicability is limited.

Alongside this general protection granted to the Crown by the English liability law, later specific legislation also exempted certain public authorities from tort liability. Examples are the Post Office Act, enacted in 1969, which exempted postal authorities from liability in tort, and the Financial Services and Markets Act, enacted in 2000, which in certain cases also exempted the commissioner from liability in tort. We will return later to the court judgments leading the Parliament of the United Kingdom to enact the latter.

\footnotetext{
${ }^{37}$ For further reading on the comparison of the tort liability of public agencies in the United States and England, see H.M. Goldberg, Liability for Government Actions: A Comparative Study of English and American Law, in Child Abuse Tort Claims Against Public Bodies: A Comparative Law View 87 (D. Fairgrieve \& S. Green eds., 2004). See also the discussion in M. Aronson, Government Liability in Negligence, 32 Melbourne U.L.R 32(44) (2008), which analyzes the law in Australia in comparison with that of England and of the United States.
}

Side by side with the aforementioned domestic legislation, England is bound, as of 2000, by the European Convention for the Protection of Human Rights and Fundamental Freedoms ${ }^{40}$ and by the European Court of Human Rights. As we shall see in the next subpart, the court judgments of the European Court of Human Rights, together with the provisions of the English Human Rights Act, are capable of influencing the considerations of the House of Lords that, in turn, have repercussions on the extent of the incorporation of human rights in the overall considerations taken into account with regard to the duty of care in the tort of negligence. Moreover, Section 8(1) of the Human Rights Act even enables English courts to award compensation when a public authority violates a right protected by the European Convention.

As for the personal liability of public employees, the perception that "The King can do no harm" did not permeate down in England to Crown employees or to its agents. If Crown employees or agents, whether senior or junior, committed a tort, this was perceived as a deed executed outside their area of competence and, consequently, they were held personally liable. This state of affairs existed alongside the institutional immunity enjoyed by the Crown, until the latter was abolished in 1946. So, until 1946, the picture of English law was that the personal liability of public employees served as a substitute for Crown liability in tort, the former being the address for filing claims and for compensation from the point of view of the injured party. At the same time, it is important to stress that, in actual fact, public authorities stood behind their employees and usually paid compensation imposed on officials.

So, we saw that after World War Two, English law parted ways with the doctrine of the immunity of the Crown, determining it was liable in tort, just like any private person. The English liability law abolished the sweeping immunity enjoyed by the Crown, grounding tort liability mainly on its agency liability for the acts of its employees and agents, with the exception of cases dealing with the direct liability of the public authority. This means that in England, the public employee, the individual, is still perceived in principle as perpetuating the tortious act and, consequently, is held personally liable. This liability spreads from them, the public employee, to the institution, that is, to the public authority. At the same time, as emerges from the data presented below, most tort claims in England are in fact filed against the public authority,

${ }^{38}$ In this context, see discussion in E.D. Borchard, Government Responsibility in Tort, 36 Yale L.J (1927) 757.

${ }^{39}$ Crown Proceedings Act (1947) §2 (hereinafter: the "English liability law"). For further reading, see also PW. Hogg, Liability of the Crown (1971).

${ }^{40}$ European Convention of Human Rights (hereinafter: the "European Convention"). 
which tends to stand behind their personally liable employees. That being the case, the question of the personal liability of public employees is of no special significance here, and is to be viewed as part of the broad issue of tort law and public authorities.

If so, how do the courts in England express considerations relating to non-interference, over-deterrence of the public authority, abuse of discretion by the latter, work overload, the floodgates argument and the unfairness of imposing liability (only for failure to prevent tortious conduct committed by another)? An analysis of the judgments below will show that the courts in England developed diverse judicial instruments to express these considerations.

\section{C.2 English court judgments}

In an attempt to trace the logic behind the many relevant judgments of the courts in England and to blaze a path through this rich entanglement, I chose to categorize them here, in this subpart, according to seven areas of activity of the modern state - maintenance of the stability of financial institutions, assurance of the safety of public ways, issue of licenses and permits, security and emergency services, the construction sector, child protection and, finally, other areas of activity (residual category). We will see shortly that this fine, precise analysis is capable of providing quite a few answers with respect to the approach adopted in English court judgments. A generalization can be made already at this stage that my fundamental conclusion in this subpart is that the remnants of the traditional approach, based on the immunity of the Crown, are still conspicuous. It emerges from the analysis below that, in every area of government activity discussed, the courts in England tend to preclude the liability of the public authority. It thus also transpires that the scope of liability of public authorities in England is similar that prevalent in United States law.

(a) Maintenance of the Stability of Financial Institutions

\begin{tabular}{|c|c|c|c|c|c|c|c|}
\hline & $\begin{array}{l}\text { Case } \\
\text { Name }\end{array}$ & $\begin{array}{c}\text { Alleged } \\
\text { Government } \\
\text { Negligence }\end{array}$ & $\begin{array}{c}\text { Was } \\
\text { Liability } \\
\text { Imposed }\end{array}$ & $\begin{array}{l}\text { Type } \\
\text { of } \\
\text { Harm }\end{array}$ & \begin{tabular}{|c|} 
Act / \\
Omission
\end{tabular} & \begin{tabular}{|c|} 
Direct / \\
Indirect \\
Tortfeasor
\end{tabular} & Remarks \\
\hline 1. & $\begin{array}{l}\text { Davis } \\
\text { v. } \\
\text { Radcli } \\
\mathrm{ffe}^{41}\end{array}$ & $\begin{array}{l}\text { Negligence of } \\
\text { financial } \\
\text { regulator, in light } \\
\text { of collapse of a } \\
\text { bank, caused } \\
\text { depositors } \\
\text { economic loss. }\end{array}$ & No & $\begin{array}{c}\text { Econo } \\
\text { mic } \\
\text { loss }\end{array}$ & Omission & $\begin{array}{c}\text { Indirect } \\
\text { tortfeasor }\end{array}$ & $\begin{array}{l}\text { The court was reluctant to award compensation } \\
\text { for pure economic loss. Moreover, it emerges } \\
\text { from its judgments that the generality of the } \\
\text { duty in this matter is inconsistent with the } \\
\text { requirement of a relationship of proximity } \\
\text { between the parties. Put differently, the court } \\
\text { maintained that liability was only imposable in } \\
\text { cases where a direct, proximate relationship } \\
\text { existed between the parties. }\end{array}$ \\
\hline 2. & $\begin{array}{l}\text { Yuen } \\
\text { Kun- } \\
\text { Yeu v. } \\
\text { A-G } \\
\text { of } \\
\text { Hong } \\
\text { Kong } \\
42\end{array}$ & $\begin{array}{l}\text { The regulatory } \\
\text { omissions of the } \\
\text { Commissioner of } \\
\text { Deposit-Taking } \\
\text { Companies } \\
\text { caused economic } \\
\text { loss to the } \\
\text { customers of a } \\
\text { bank that } \\
\text { collapsed. }\end{array}$ & $\mathrm{No}$ & $\begin{array}{c}\text { Econo } \\
\text { mic } \\
\text { loss }\end{array}$ & Omission & $\begin{array}{l}\text { Indirect } \\
\text { tortfeasor }\end{array}$ & $\begin{array}{l}\text { In this case, too, the court was reluctant to award } \\
\text { compensation for pure economic loss. It emerges } \\
\text { from its judgment that the generality of the duty } \\
\text { of care in this matter is inconsistent with the } \\
\text { requirement of a relationship of proximity } \\
\text { between the parties. Put simply, the court } \\
\text { examines the relationship of neighborhood } \\
\text { between the Commissioner of Deposit-Taking } \\
\text { Companies and the injured party, and } \\
\text { determines that a relationship of neighborhood } \\
\text { exists when the injured party is harmed directly } \\
\text { and proximally by an action performed by } \\
\text { another, unlike this case. }\end{array}$ \\
\hline
\end{tabular}

\section{Summary of this area of activity}

In this area of activity, English court judgments precludes tort liability on the part of the public authority. Its duty in this context is perceived as a general duty towards investors as a public, not as a special duty towards a specific injured investor. It appears this approach is based on concern about the over-deterrence of the regulatory authorities, the unleashing of a torrent of claims, and disruption of ongoing government activity. As we saw during the presentation of the legislative framework, the lawmaker - in the context of this category of government activity - fell in line with court judgments when the Financial Services and Markets Act was enacted in 2000, extending an exemption from tort liability to regulators under certain circumstances.

${ }^{41}$ Davis v. Radcliffe, [1990] 1 WLR. 821 (UKPC). Yuen Kun-Yeu v. A-G of Hong Kong, [1987] 1 All E. 705. ${ }^{42}$ 
(b) Assurance of the Safety of Public Ways

\begin{tabular}{|c|c|c|c|c|c|c|c|}
\hline & Case Name & $\begin{array}{l}\text { Alleged Government } \\
\text { Negligence }\end{array}$ & $\begin{array}{l}\text { Was } \\
\text { Liability } \\
\text { Imposed }\end{array}$ & $\begin{array}{l}\text { Type of } \\
\text { Harm }\end{array}$ & $\begin{array}{c}\text { Act / } \\
\text { Omission }\end{array}$ & $\begin{array}{c}\text { Direct / } \\
\text { Indirect } \\
\text { Tortfeasor }\end{array}$ & Remarks \\
\hline 1. & $\begin{array}{l}\text { Ancell v. } \\
\text { McDermott } \\
43\end{array}$ & $\begin{array}{l}\text { Failure of police } \\
\text { officers to remove } \\
\text { a diesel trail from } \\
\text { the road, causing } \\
\text { a traffic accident. }\end{array}$ & No & $\begin{array}{c}\text { Physical } \\
\text { harm }\end{array}$ & Omission & $\begin{array}{c}\text { Indirect } \\
\text { tortfeasor }\end{array}$ & $\begin{array}{l}\text { The court determined that the generality of } \\
\text { the duty in this matter was inconsistent } \\
\text { with the requirement of a relationship of } \\
\text { proximity between the parties. }\end{array}$ \\
\hline 2. & $\begin{array}{l}\text { Gorringe v. } \\
\text { Calderdale } \\
\text { Metropolita } \\
\text { n Borough } \\
\text { Council }^{44}\end{array}$ & $\begin{array}{l}\text { Failure of the local } \\
\text { authority to } \\
\text { appropriately } \\
\text { maintain a public } \\
\text { highway. }\end{array}$ & No & $\begin{array}{c}\text { Physical } \\
\text { harm }\end{array}$ & Omission & $\begin{array}{l}\text { Direct } \\
\text { tortfeasor }\end{array}$ & $\begin{array}{l}\text { The court rejected the claim on the grounds } \\
\text { of the requirement of proximity and } \\
\text { reluctance to impose liability for the } \\
\text { omissions of the local authority, rather } \\
\text { than for its acts. }\end{array}$ \\
\hline 3. & $\begin{array}{l}\text { Stovin v. } \\
\text { Wise }^{45}\end{array}$ & $\begin{array}{l}\text { The highway } \\
\text { authority failed to } \\
\text { appropriately } \\
\text { maintain the signs } \\
\text { within its } \\
\text { jurisdiction. As a } \\
\text { result, one of the } \\
\text { signs was covered } \\
\text { with vegetation, } \\
\text { causing a traffic } \\
\text { accident. }\end{array}$ & No & $\begin{array}{c}\text { Physical } \\
\text { harm }\end{array}$ & Omission & $\begin{array}{c}\text { Direct } \\
\text { tortfeasor }\end{array}$ & $\begin{array}{l}\text { The court rejected the claim, relying on the } \\
\text { requirement of a relationship of proximity } \\
\text { and reluctance to impose liability for the } \\
\text { omissions of the highway authority. }\end{array}$ \\
\hline
\end{tabular}

\section{Summary of this area of activity}

This area of activity is characterized by the reluctance of English law to impose tort liability, the position of case law here being that the generality of the duty of the public authority in such cases is inconsistent with the requirement of a special relationship of proximity between the parties to the accident. Hence, tort liability is not to be imposed on the public authorities in these cases.

(c) Issue of Licenses and Permits

\begin{tabular}{|c|c|c|c|c|c|c|c|}
\hline & Case Name & $\begin{array}{c}\text { Alleged Government } \\
\text { Negligence }\end{array}$ & $\begin{array}{c}\text { Was } \\
\text { Liability } \\
\text { Imposed } \\
\end{array}$ & $\begin{array}{l}\text { Type of } \\
\text { Harm }\end{array}$ & $\begin{array}{c}\text { Act / } \\
\text { Omission }\end{array}$ & $\begin{array}{l}\text { Direct / } \\
\text { Indirect } \\
\text { Tortfeasor }\end{array}$ & Remarks \\
\hline 1. & $\begin{array}{l}\text { Dunlop v. } \\
\text { Woollahra } \\
\text { Municipal } \\
\text { Council }^{46}\end{array}$ & $\begin{array}{l}\text { Revocation of } \\
\text { license, } \\
\text { preventing the } \\
\text { injured party from } \\
\text { continuing to } \\
\text { manage his } \\
\text { business. }\end{array}$ & No & $\begin{array}{l}\text { Economic } \\
\text { loss }\end{array}$ & Act & $\begin{array}{c}\text { Direct } \\
\text { tortfeasor }\end{array}$ & $\begin{array}{l}\text { The court rejected the claim in view of } \\
\text { its reluctance to award compensation } \\
\text { for pure economic loss. }\end{array}$ \\
\hline 2. & $\begin{array}{l}\text { Trent } \\
\text { Strategic } \\
\text { Health } \\
\text { Authority } \\
\text { v. Jain }{ }^{47}\end{array}$ & $\begin{array}{l}\text { Decision by health } \\
\text { authority to close } \\
\text { the business of the } \\
\text { claimants. }\end{array}$ & No & $\begin{array}{c}\text { Economic } \\
\text { loss }\end{array}$ & Act & $\begin{array}{c}\text { Direct } \\
\text { tortfeasor }\end{array}$ & $\begin{array}{l}\text { The court rejected the claim in light of } \\
\text { its reluctance to award compensation } \\
\text { for pure economic loss. }\end{array}$ \\
\hline 3. & $\begin{array}{l}\text { Murphy v. } \\
\text { Brentwood } \\
\text { District }\end{array}$ & $\begin{array}{l}\text { Negligence of } \\
\text { local authority in } \\
\text { supervision of } \\
\text { building plans }\end{array}$ & No & $\begin{array}{l}\text { Economic } \\
\text { loss }\end{array}$ & Omission & $\begin{array}{l}\text { Indirect } \\
\text { tortfeasor }\end{array}$ & $\begin{array}{l}\text { The court ruled that imposition of } \\
\text { liability on a local authority for failing } \\
\text { to take reasonable measures to save a } \\
\text { house buyer from economic loss was }\end{array}$ \\
\hline
\end{tabular}

\footnotetext{
${ }^{43}$ Ancell v. McDermott [1993] RTR 235 (EWCA Civ).

Gorringe v. Calderdale Metropolitan Borough Council [2001] 1 WLR 1057 (HL). ${ }^{44}$

${ }^{45}$ Stovin v. Wise [1996] AC 923 (HL).

${ }^{46}$ Dunlop v. Woollahra Municipal Council [1982] AC 158 (HL).

Trent Strategic Health Authority v. Jain [2009] 1 All ER 957. ${ }^{47}$
} 


\begin{tabular}{|l|l|l|l|l|l|l|l|}
\hline & Council $^{48}$ & $\begin{array}{l}\text { submitted to it for } \\
\text { approval. }\end{array}$ & & & & $\begin{array}{l}\text { an undesirable widening of the } \\
\text { boundaries of liability, due to policy } \\
\text { considerations such as the requirement } \\
\text { of a relationship of proximity between } \\
\text { the parties, and reluctance to recognize } \\
\text { pure economic loss as compensable. }\end{array}$ \\
\hline 4. & $\begin{array}{l}\text { Perrett v. } \\
\text { Collins }{ }^{49}\end{array}$ & $\begin{array}{l}\text { Negligence of the } \\
\text { public authority } \\
\text { responsible for } \\
\text { licensing aircraft. }\end{array}$ & Yes & $\begin{array}{l}\text { Physical } \\
\text { harm }\end{array}$ & Omission & $\begin{array}{c}\text { Direct } \\
\text { tortfeasor }\end{array}$ & $\begin{array}{l}\text { The claim was accepted, in particular } \\
\text { in view of the fact that the case related } \\
\text { to a matter of physical harm. }\end{array}$ \\
\hline
\end{tabular}

\section{Summary of this area of activity}

As can be seen, in this area of activity of public authorities too, the courts in England tend to preclude liability. This preclusion of liability stresses how widespread is the traditional liability-limiting approach in English law, for several reasons. First, in these cases the public authority is usually the direct tortfeasor. Second, it is a matter of a harm caused by an act of the public authority, not by an omission on its part. Finally, the injured party is usually engaged in prolonged, continuous communication with the public authority and, that being the case, that relationship of proximity and neighborhood that constitutes a requirement for the imposition of liability is sometimes created. In spite of this, the courts in England prefer to adopt a cautious, traditional approach to everything concerning the imposition of liability for pure economic loss. This distinction may even be capable of explaining why the only case in English law where liability was imposed in this area of activity was in the Perrett case, which dealt, as noted, with physical harm.

\section{(d) Security and Emergency Services}

\begin{tabular}{|c|c|c|c|c|c|c|c|}
\hline & Judgment & $\begin{array}{c}\text { Alleged Government } \\
\text { Negligence }\end{array}$ & $\begin{array}{c}\text { Was } \\
\text { Liability } \\
\text { Imposed }\end{array}$ & $\begin{array}{l}\text { Type of } \\
\text { Harm }\end{array}$ & $\begin{array}{l}\text { Act / } \\
\text { Omission }\end{array}$ & $\begin{array}{c}\text { Direct / } \\
\text { Indirect } \\
\text { Tortfeasor }\end{array}$ & Remarks \\
\hline $\begin{array}{l}1 \\
\cdot\end{array}$ & $\begin{array}{l}\text { Ancell v. } \\
\text { McDermott }^{50}\end{array}$ & $\begin{array}{l}\text { Police officers } \\
\text { failed to vacate a } \\
\text { diesel trail from } \\
\text { the road, which } \\
\text { led to a traffic } \\
\text { accident. }\end{array}$ & No & $\begin{array}{l}\text { Physical } \\
\text { harm }\end{array}$ & Omission & $\begin{array}{l}\text { Indirect } \\
\text { tortfeasor }\end{array}$ & $\begin{array}{l}\text { The court rejected the claim on the } \\
\text { grounds that the generality of the duty } \\
\text { in this matter was inconsistent with the } \\
\text { requirement of a relationship of } \\
\text { proximity between the parties. }\end{array}$ \\
\hline $\begin{array}{l}2 \\
\cdot\end{array}$ & $\begin{array}{l}\text { Brooks v. } \\
\text { Commissione } \\
r \text { of Police for } \\
\text { the } \\
\text { Metropolis }^{51}\end{array}$ & $\begin{array}{l}\text { Failure in duty of } \\
\text { care owed by the } \\
\text { police department } \\
\text { to crime victim. }\end{array}$ & No & $\begin{array}{l}\text { Physical } \\
\text { harm }\end{array}$ & Omission & $\begin{array}{l}\text { Indirect } \\
\text { tortfeasor }\end{array}$ & $\begin{array}{l}\text { The court judgment deliberated the } \\
\text { issue whether the police department } \\
\text { was obligated to take reasonable } \\
\text { measures to assess whether the claimant } \\
\text { was indeed a crime victim, with the aim } \\
\text { of extending reasonable protection, as } \\
\text { well as appropriate support and } \\
\text { assistance. The court ruled that, as a } \\
\text { matter of public policy, the police } \\
\text { department did not owe a duty of } \\
\text { general care towards victims and } \\
\text { witnesses while investigating a } \\
\text { suspicion of crime. Such a duty would } \\
\text { harm police freedom of action. }\end{array}$ \\
\hline 3 & $\begin{array}{l}\text { Calveley v. } \\
\text { Chief } \\
\text { Constable of } \\
\text { Merseyside }^{52}\end{array}$ & $\begin{array}{l}\text { Police officers } \\
\text { contended that a } \\
\text { disciplinary } \\
\text { investigation } \\
\text { conducted against } \\
\text { them caused them } \\
\text { harm. }\end{array}$ & No & $\begin{array}{l}\text { Anxiety } \\
\text { and } \\
\text { damaged } \\
\text { reputatio } \\
\mathrm{n}\end{array}$ & Act & $\begin{array}{l}\text { Direct } \\
\text { tortfeasor }\end{array}$ & $\begin{array}{l}\text { The claim was rejected, mainly due to } \\
\text { the court's reluctance to award } \\
\text { compensation for pure economic loss or } \\
\text { for pure emotional harm. }\end{array}$ \\
\hline
\end{tabular}

\footnotetext{
${ }^{48}$ Murphy v. Brentwood District Council [1991] 1 AC 398 (HL 1990).

${ }^{49}$ Perrett v. Collins [1999] PNLR 77 (EWCA Civ 1998).

${ }^{50}$ Ancell v. McDermott [1993] RTR 235 (EWCA Civ).

Brooks v. Commissioner of Police for the Metropolis [2005] 1 WLR 1495 (HL). ${ }^{51}$

${ }^{52}$ Calveley v. Chief Constable of Merseyside [1989] A.C. 1228.
} 


\begin{tabular}{|c|c|c|c|c|c|c|c|}
\hline $\begin{array}{l}4 \\
.\end{array}$ & $\begin{array}{l}\text { Capital and } \\
\text { Counties Plc } \\
\text { v. Hampshire } \\
\text { County } \\
\text { Council }^{53}\end{array}$ & $\begin{array}{l}\text { The fire services } \\
\text { failed to arrive in } \\
\text { a timely fashion } \\
\text { due to negligence } \\
\text { of the driver. }\end{array}$ & No & $\begin{array}{l}\text { Property } \\
\text { damage }\end{array}$ & Omission & $\begin{array}{c}\text { Indirect } \\
\text { tortfeasor }\end{array}$ & $\begin{array}{l}\text { The claim was rejected, mainly in view } \\
\text { of the aim to limit the liability of public } \\
\text { authorities when the negligence in } \\
\text { question arises out of an omission. }\end{array}$ \\
\hline 5 & $\begin{array}{l}\text { Desmond v. } \\
\text { Chief } \\
\text { Constable of } \\
\text { Nottinghams } \\
\text { hire Police }^{54}\end{array}$ & $\begin{array}{l}\text { Failure of police } \\
\text { department to } \\
\text { provide correct } \\
\text { updated } \\
\text { information on the } \\
\text { criminal } \\
\text { background of the } \\
\text { claimant. }\end{array}$ & No & $\begin{array}{l}\text { Damage } \\
\text { to good } \\
\text { name and } \\
\text { reputatio } \\
\text { n, as well } \\
\text { as } \\
\text { economic } \\
\text { loss }\end{array}$ & Omission & $\begin{array}{c}\text { Direct } \\
\text { tortfeasor }\end{array}$ & $\begin{array}{l}\text { The court judgment elaborated on the } \\
\text { fact that not only does the existence of a } \\
\text { legislative mandate not constitute a } \\
\text { consideration for imposing liability on } \\
\text { the public authority but, on the contrary, } \\
\text { it constitutes weighty grounds for the } \\
\text { preclusion of such liability. }\end{array}$ \\
\hline $\begin{array}{l}6 \\
.\end{array}$ & $\begin{array}{l}\text { Hill v. Chief } \\
\text { Constable of } \\
\text { West } \\
\text { Yorkshire }\end{array}$ & $\begin{array}{l}\text { Negligent } \\
\text { investigation of a } \\
\text { series of murders, } \\
\text { leading to failure } \\
\text { to apprehend a } \\
\text { murderer, who } \\
\text { committed } \\
\text { another murder - } \\
\text { in the home of the } \\
\text { claimant. }\end{array}$ & No & $\begin{array}{c}\text { Physical } \\
\text { harm }\end{array}$ & Omission & $\begin{array}{l}\text { Indirect } \\
\text { tortfeasor }\end{array}$ & $\begin{array}{l}\text { The court rejected the claim, on two } \\
\text { main grounds: no special relationship of } \\
\text { proximity or neighborhood existed } \\
\text { between the crime victim and the police } \\
\text { department concern that imposition of } \\
\text { liability on the police department under } \\
\text { such circumstances would harm its } \\
\text { proper functioning. }\end{array}$ \\
\hline $\begin{array}{l}7 \\
.\end{array}$ & $\begin{array}{l}\text { Kirkham v. } \\
\text { Chief } \\
\text { Constable of } \\
\text { the Greater } \\
\text { Manchester } \\
\text { Police }^{56}\end{array}$ & $\begin{array}{l}\text { Failure of the } \\
\text { police department } \\
\text { to prevent a } \\
\text { prisoner with } \\
\text { suicidal } \\
\text { tendencies from } \\
\text { committing } \\
\text { suicide in a } \\
\text { remand center. }\end{array}$ & Yes & $\begin{array}{c}\text { Physical } \\
\text { harm }\end{array}$ & Omission & $\begin{array}{c}\text { Indirect } \\
\text { tortfeasor }\end{array}$ & $\begin{array}{l}\text { The court judgment clarified that the } \\
\text { circumstances of the case created an } \\
\text { active hazard. In addition, this was not a } \\
\text { matter of the use of broad discretion, } \\
\text { and the negligence of the public } \\
\text { authority caused the gravest of harms. }\end{array}$ \\
\hline $\begin{array}{l}8 \\
\cdot\end{array}$ & $\begin{array}{l}\text { Mitchell v. } \\
\text { Glasgow City } \\
\text { Council }^{57}\end{array}$ & $\begin{array}{l}\text { Due to negligence } \\
\text { of a local council } \\
\text { that provided } \\
\text { housing, one } \\
\text { tenant murdered } \\
\text { another tenant. }\end{array}$ & Yes & $\begin{array}{l}\text { Physical } \\
\text { harm }\end{array}$ & Omission & $\begin{array}{c}\text { Indirect } \\
\text { tortfeasor }\end{array}$ & $\begin{array}{l}\text { In this case, liability was imposed on the } \\
\text { public authority in view of the special } \\
\text { relationship of proximity created } \\
\text { between it and the victim. }\end{array}$ \\
\hline $\begin{array}{l}9 \\
.\end{array}$ & $\begin{array}{l}\text { Osman v. } \\
\text { Ferguson }^{58}\end{array}$ & $\begin{array}{l}\text { Failure of police } \\
\text { department to } \\
\text { prevent a teacher } \\
\text { attacking a } \\
\text { student and } \\
\text { murdering the } \\
\text { student's father, } \\
\text { despite repeated } \\
\text { alerts that the } \\
\text { murderer was } \\
\text { dangerous. }\end{array}$ & No & $\begin{array}{c}\text { Physical } \\
\text { harm }\end{array}$ & Omission & $\begin{array}{c}\text { Indirect } \\
\text { tortfeasor }\end{array}$ & $\begin{array}{l}\text { The court determined that the family } \\
\text { had no cause of action whatsoever } \\
\text { against the police department. }\end{array}$ \\
\hline $\begin{array}{l}1 \\
0 \\
.\end{array}$ & $\begin{array}{l}\text { Rigby v. } \\
\text { Constable of } \\
\text { Northampton }\end{array}$ & $\begin{array}{l}\text { 1. Failure of police } \\
\text { department to } \\
\text { acquire special CS }\end{array}$ & $\begin{array}{c}\text { No, with } \\
\text { respect to } \\
\text { first }\end{array}$ & \begin{tabular}{|l|} 
Mainly \\
property \\
damage
\end{tabular} & Omission, & $\begin{array}{l}\text { Indirect } \\
\text { tortfeasor }\end{array}$ & $\begin{array}{l}\text { The first allegation of negligence was } \\
\text { rejected on the grounds of the } \\
\text { discretionary exception. }\end{array}$ \\
\hline
\end{tabular}

\footnotetext{
${ }^{53}$ Capital and Counties Plc v. Hampshire County Council [1997] QB 1004(EWCA Civ).

${ }^{54}$ Desmond v. Chief Constable of Nottinghamshire Police [2011] PTSR 1369 (EWCA Civ).

${ }^{55}$ Hill v. Chief Constable of West Yorkshire [1989] A. C. 53 (H.L 1988)

${ }^{56}$ Kirkham v. Chief Constable of the Greater Manchester Police [1990] 2 W.L.R 987.

${ }^{57}$ Mitchell v. Glasgow City Council [2009] 2 WLR 481 (HL).

${ }^{58}$ Osman v. United Kingdom [1998] ECHR 101 (Eur Ct HR).
} 


\begin{tabular}{|c|c|c|c|c|c|c|c|}
\hline & shire $^{59}$ & $\begin{array}{l}\text { gas device. } \\
\text { 2. In view of this, } \\
\text { there was no room } \\
\text { to open fire. }\end{array}$ & $\begin{array}{c}\text { allegation } \\
\text {; and yes, } \\
\text { with } \\
\text { respect to } \\
\text { second } \\
\text { allegation } \\
\text {. }\end{array}$ & & $\begin{array}{c}\text { first } \\
\text { allegation } \\
\text {; and act } \\
\text { with } \\
\text { respect to } \\
\text { second } \\
\text { allegation }\end{array}$ & & \\
\hline $\begin{array}{l}1 \\
1 \\
.\end{array}$ & $\begin{array}{l}\text { Smith v. } \\
\text { Chief } \\
\text { Constable of } \\
\text { Sussex } \\
\text { Police }^{60}\end{array}$ & $\begin{array}{l}\text { Failure of the } \\
\text { police department } \\
\text { to prevent the } \\
\text { claimant's } \\
\text { business partner } \\
\text { from attacking } \\
\text { him, in spite of his } \\
\text { complaints and } \\
\text { alerts. }\end{array}$ & No & $\begin{array}{c}\text { Physical } \\
\text { harm }\end{array}$ & Omission & $\begin{array}{l}\text { Indirect } \\
\text { tortfeasor }\end{array}$ & $\begin{array}{l}\text { The court rejected the claim, relying on } \\
\text { the requirement of a relationship of } \\
\text { proximity and on the public duty } \\
\text { doctrine. }\end{array}$ \\
\hline
\end{tabular}

\section{Summary of this area of activity}

Analysis of the judgments in this area of activity reveals that courts in England tend to reject tort claims filed against public authorities that provide security and emergency services. In spite of the fact that the harms caused in this area of public authority activity are frequently personal injuries, it is usually a matter of failure to prevent unlawful injurious conduct committed by another. In other words, the direct cause of the claimant's harms in these cases is not the public authority but, rather, the tort of another. The courts in England exempt authorities from liability, relying both on the public duty doctrine (according to which the powers and duties of public authorities are addressed to society as a collective, not to the injured party as an individual and, consequently, their breach does not provide the individual injured party with a cause of tort action), as well as on reluctance to impose liability on public authorities for their omissions (to distinguish from the imposition of liability for their acts).

(e) The Construction Sector

\begin{tabular}{|c|c|c|c|c|c|c|c|}
\hline & Case Name & $\begin{array}{c}\text { Alleged } \\
\text { Government } \\
\text { Negligence }\end{array}$ & $\begin{array}{c}\text { Was } \\
\text { Liability } \\
\text { Imposed }\end{array}$ & $\begin{array}{c}\text { Type of } \\
\text { Harm }\end{array}$ & $\begin{array}{c}\text { Act / } \\
\text { Omission }\end{array}$ & \begin{tabular}{c|} 
Direct / \\
Indirect \\
Tortfeasor
\end{tabular} & Remarks \\
\hline 1. & $\begin{array}{l}\text { Anns v. } \\
\text { Merton } \\
\text { London } \\
\text { Borough } \\
\text { Council }^{61}\end{array}$ & $\begin{array}{l}\text { Negligent } \\
\text { testing of } \\
\text { building } \\
\text { safety. }\end{array}$ & Yes & $\begin{array}{c}\text { Economic } \\
\text { loss }\end{array}$ & Omission & $\begin{array}{c}\text { Indirect } \\
\text { tortfeasor }\end{array}$ & $\begin{array}{l}\text { The court ruled in favor of the claimant, } \\
\text { relying in particular on the distinction } \\
\text { between discretion exercised at the } \\
\text { planning level and discretion exercised at } \\
\text { the operational level, and on its } \\
\text { determination that the manner of } \\
\text { inspection of the foundations of the } \\
\text { building in question constituted } \\
\text { negligence at the operational level, which } \\
\text { is subject to judicial review. }\end{array}$ \\
\hline 2. & $\begin{array}{l}\text { Dutton v. } \\
\text { Bognor } \\
\text { Regis Urban } \\
\text { District } \\
\text { Council }^{62}\end{array}$ & $\begin{array}{l}\text { Negligent } \\
\text { inspection by } \\
\text { District } \\
\text { Council of } \\
\text { soundness of } \\
\text { house. }\end{array}$ & Yes & $\begin{array}{l}\text { Property } \\
\text { damage } \\
\text { and } \\
\text { economic } \\
\text { loss }\end{array}$ & Omission & $\begin{array}{l}\text { Indirect } \\
\text { tortfeasor }\end{array}$ & $\begin{array}{l}\text { In this case, liability was imposed with } \\
\text { respect to the negligent exercise of } \\
\text { inspection powers in the construction } \\
\text { sector. }\end{array}$ \\
\hline 3. & $\begin{array}{l}\text { East Suffolk } \\
\text { Rivers } \\
\text { Catchment } \\
\text { Board v. }\end{array}$ & $\begin{array}{l}\text { Negligent } \\
\text { exercise of } \\
\text { powers by } \\
\text { local } \\
\text { authority to }\end{array}$ & No & $\begin{array}{l}\text { Property } \\
\text { damage }\end{array}$ & Omission & $\begin{array}{c}\text { Direct } \\
\text { tortfeasor }\end{array}$ & $\begin{array}{l}\text { In this case, the court relied on the rule } \\
\text { according to which a local authority } \\
\text { vested with the discretion to decide } \\
\text { whether to exercise its powers - to } \\
\text { distinguish from a specific duty to act or }\end{array}$ \\
\hline
\end{tabular}

\footnotetext{
${ }^{59}$ Rigby v. Constable of Northamptonshire, [1985] 1 WLR 1242 (QBD).

${ }^{60}$ Smith v. Chief Constable of Sussex Police [2009] AC 225.

${ }^{61}$ Anns v. Merton London Borough Council [1978] AC 728 (HL 1977).

1 QB 373.]1972[Dutton v. Bognor Regis Urban District Council ${ }^{62}$
} 


\begin{tabular}{|c|c|c|c|c|c|c|c|}
\hline & $\operatorname{Ken}^{63}$ & $\begin{array}{l}\text { block a } \\
\text { breach in the } \\
\text { wall that } \\
\text { protected the } \\
\text { claimant } \\
\text { against flood } \\
\text { damage. }\end{array}$ & & & & & to omit to act - is not liable in tort. \\
\hline 4. & $\begin{array}{l}\text { Murphy v. } \\
\text { Brentwood } \\
\text { District } \\
\text { Council }^{64}\end{array}$ & $\begin{array}{l}\text { Negligent } \\
\text { checking by } \\
\text { supervisory } \\
\text { authority of } \\
\text { building } \\
\text { plans } \\
\text { submitted for } \\
\text { its approval. }\end{array}$ & No & $\begin{array}{c}\text { Economic } \\
\text { loss }\end{array}$ & Omission & $\begin{array}{l}\text { Indirect } \\
\text { tortfeasor }\end{array}$ & $\begin{array}{l}\text { In this case, the House of Lords held that } \\
\text { the imposition of liability on a } \\
\text { supervisory authority - to take } \\
\text { reasonable measures to save a house } \\
\text { buyer from economic loss - was an } \\
\text { undesirable expansion of the boundaries } \\
\text { of liability for the following policy } \\
\text { considerations: in such matters, the court } \\
\text { must focus on the question of proximity, } \\
\text { which did not exist in this case; and due } \\
\text { to the harm being pure economic loss. }\end{array}$ \\
\hline
\end{tabular}

Summary of this area of activity

The involvement of the Crown and its agencies in the construction sector at all its stages - planning, execution, and inspection - is extensive and, consequently, this area of activity creates a major potential for causing harm, which often constitutes economic loss. The imposition of liability for such harms poses a problem for the English legal system as it does, as we saw, for the United States legal system. Court judgments in England, much like in the United States, tend to limit recognize the existence of the duty of care with respect to such harms, and does so only when special conditions exist.

(f) Child Protection

\begin{tabular}{|c|c|c|c|c|c|c|c|}
\hline & Case Name & $\begin{array}{l}\text { Alleged Government } \\
\text { Negligence }\end{array}$ & $\begin{array}{l}\text { Was Liability } \\
\text { Imposed }\end{array}$ & $\begin{array}{c}\text { Type of } \\
\text { Harm }\end{array}$ & $\begin{array}{c}\text { Act / } \\
\text { Omission }\end{array}$ & $\begin{array}{c}\text { Direct / } \\
\text { Indirect } \\
\text { Tortfeasor } \\
\end{array}$ & Remarks \\
\hline 1. & $\begin{array}{l}\text { Barrett v. } \\
\text { Enfield } \\
\text { London } \\
\text { Borough } \\
\text { Council }^{65}\end{array}$ & $\begin{array}{l}\text { Failure of social services } \\
\text { to locate an appropriate } \\
\text { foster family for a } \\
\text { minor under its care, as } \\
\text { well as to supervise the } \\
\text { return of the minor to } \\
\text { his biological mother. }\end{array}$ & $\begin{array}{l}\text { The House of } \\
\text { Lords refused } \\
\text { to absolutely } \\
\text { preclude } \\
\text { recognition of } \\
\text { the duty of } \\
\text { care owed by } \\
\text { social services } \\
\text { to the minor. }\end{array}$ & $\begin{array}{l}\text { Emotional } \\
\text { harm }\end{array}$ & Omission & $\begin{array}{c}\text { Direct } \\
\text { tortfeasor }\end{array}$ & $\begin{array}{l}\text { The court elaborated on the } \\
\text { existence of the } \\
\text { requirement of a } \\
\text { relationship of proximity in } \\
\text { this case. }\end{array}$ \\
\hline 2. & $\begin{array}{l}\text { AD and } \\
\text { another v. } \\
\text { Bury } \\
\text { Metropolitan } \\
\text { Borough } \\
\text { Council }^{66}\end{array}$ & $\begin{array}{l}\text { Negligence of social } \\
\text { services in removing a } \\
\text { minor from the custody } \\
\text { of his biological } \\
\text { parents. }\end{array}$ & No & $\begin{array}{l}\text { Emotional } \\
\text { harm }\end{array}$ & Act & $\begin{array}{l}\text { Direct } \\
\text { tortfeasor }\end{array}$ & $\begin{array}{l}\text { The claim was rejected, in } \\
\text { particular out of reluctance } \\
\text { to award compensation for } \\
\text { pure emotional harm. }\end{array}$ \\
\hline 3. & $\begin{array}{l}\text { JD v. East } \\
\text { Berkshire } \\
\text { Community } \\
\text { Health NHS } \\
\text { Trust }^{67}\end{array}$ & $\begin{array}{l}\text { Harm to a child who, } \\
\text { due to an erroneous } \\
\text { expert opinion, was } \\
\text { removed by social } \\
\text { services from the } \\
\text { custody of his parents } \\
\text { and placed with a foster }\end{array}$ & Yes & $\begin{array}{l}\text { Physical } \\
\text { harm, } \\
\text { causing } \\
\text { emotional } \\
\text { harm }\end{array}$ & Act & $\begin{array}{l}\text { Indirect } \\
\text { tortfeasor }\end{array}$ & $\begin{array}{l}\text { The claim was accepted in } \\
\text { light of the fact that it } \\
\text { related to physical harm } \\
\text { that led to emotional harm. }\end{array}$ \\
\hline
\end{tabular}

\footnotetext{
${ }^{63}$ East Suffolk Rivers Catchment Board v. Kent [1941] AC 74 (HL 1940).

${ }^{64}$ Murphy v. Brentwood District Council [1991] 1 AC 398 (HL 1990).

${ }^{65}$ Barrett v. Enfield London Borough Council, [2001] 2 AC 550 (HL 1999).
}

AD and another v. Bury Metropolitan Borough Council [2006] EWCA Civ 1 (AC). ${ }^{66}$

${ }^{67}$ JD v. East Berkshire Community Health NHS Trust [2004] QB 558 (EWCA Civ 2003). 


\begin{tabular}{|c|c|c|c|c|c|c|c|}
\hline & & $\begin{array}{l}\text { family, where he } \\
\text { suffered. }\end{array}$ & & & & & \\
\hline 4. & $\begin{array}{l}\text { JD v. East } \\
\text { Berkshire } \\
\text { Community } \\
\text { Health NHS } \\
\text { Trust }^{68}\end{array}$ & $\begin{array}{l}\text { Claim filed by the } \\
\text { parents of a child who } \\
\text { was erroneously } \\
\text { removed by social } \\
\text { services from their } \\
\text { custody. }\end{array}$ & No & $\begin{array}{l}\text { Emotional } \\
\text { harm }\end{array}$ & Act & $\begin{array}{c}\text { Direct } \\
\text { tortfeasor }\end{array}$ & $\begin{array}{l}\text { The claim was rejected, } \\
\text { mainly due to reluctance to } \\
\text { award compensation for } \\
\text { pure emotional harm. }\end{array}$ \\
\hline 5. & $\begin{array}{l}\text { Home Office } \\
\text { v. Dorset } \\
\text { Yacht Co. } \\
\text { Ltd }^{69}\end{array}$ & $\begin{array}{l}\text { Negligent supervision } \\
\text { by social services of } \\
\text { rehabilitated youths } \\
\text { working under their } \\
\text { care. }\end{array}$ & Yes & $\begin{array}{l}\text { Mainly } \\
\text { property } \\
\text { damage }\end{array}$ & Omission & $\begin{array}{l}\text { Indirect } \\
\text { tortfeasor }\end{array}$ & $\begin{array}{l}\text { The court elaborated on the } \\
\text { existence of the } \\
\text { requirement of a special } \\
\text { relationship of proximity in } \\
\text { this matter. }\end{array}$ \\
\hline 6. & $\begin{array}{l}\mathrm{X} \& \mathrm{Y} \mathrm{v} . \\
\text { London } \\
\text { Borough of } \\
\text { Hounslow }^{70}\end{array}$ & $\begin{array}{l}\text { Responsibility of the } \\
\text { social services for the } \\
\text { welfare of minors and } \\
\text { to protect them from } \\
\text { others. }\end{array}$ & No & $\begin{array}{l}\text { Physical } \\
\text { harm and } \\
\text { emotional } \\
\text { harm }\end{array}$ & Omission & $\begin{array}{l}\text { Indirect } \\
\text { tortfeasor }\end{array}$ & $\begin{array}{l}\text { In rejecting the claim, the } \\
\text { court elaborated on the } \\
\text { importance of the existence } \\
\text { of a special relationship of } \\
\text { proximity and of } \\
\text { distinguishing between an } \\
\text { act of the social services } \\
\text { and between an omissions } \\
\text { on their part. }\end{array}$ \\
\hline 7. & $\begin{array}{l}\text { X v. } \\
\text { Bedfordshire } \\
\text { County } \\
\text { Council }^{71}\end{array}$ & $\begin{array}{l}\text { Responsibility of social } \\
\text { services to see to the } \\
\text { welfare of minors and } \\
\text { to protect them. }\end{array}$ & No & $\begin{array}{c}\text { Physical } \\
\text { harm }\end{array}$ & Omission & $\begin{array}{l}\text { Indirect } \\
\text { tortfeasor }\end{array}$ & $\begin{array}{l}\text { In rejecting the claim, the } \\
\text { court elaborated on the } \\
\text { importance of the } \\
\text { following: } \\
\text { discretionary exception; } \\
\text { the public duty doctrine; } \\
\text { and the distinction between } \\
\text { an act on the part of the } \\
\text { social services and between } \\
\text { an omissions on their part. }\end{array}$ \\
\hline
\end{tabular}

\section{Summary of this area of activity}

The imposition of liability in this area of public authority activity does not go without saying. It transpires from an analysis of the data that, in this area of activity too, the courts in England frequently tend to rule that the social services do not owe a duty of care and do not bear liability, either directly or by imputation, for harms caused to minors. "Liability filters" are utilized by the courts in England as a matter of course in the following manner: In some cases in this area of activity, it is a matter of omissions, not acts, by the social services; sometimes that special relationship of proximity does not exist between the social services and the injured party; the duties of the social services are perceived as public duties; and they are usually vested with broad discretion with respect to the manner of handling the matter at hand. All these lead to narrow, limited liability. In those cases where the court is inclined to impose liability, this is due to those "filters", as in the case where the court determined that once the social services take the minor under their protection, that same relationship of proximity is weaved that also justifies the imposition of liability. ${ }^{72}$

(g) Other Areas of Activity (residual category)

\begin{tabular}{|l|l|l|c|c|c|c|c|}
\hline & Case Name & $\begin{array}{c}\text { Alleged } \\
\text { Government } \\
\text { Negligence }\end{array}$ & $\begin{array}{c}\text { Was } \\
\text { Liability } \\
\text { Imposed }\end{array}$ & $\begin{array}{c}\text { Type of } \\
\text { Harm }\end{array}$ & Act / Omission & $\begin{array}{c}\text { Direct / } \\
\text { Indirect } \\
\text { Tortfeasor }\end{array}$ & Remarks \\
\hline 1. & $\begin{array}{l}\text { Connor v. } \\
\text { Surrey }\end{array}$ & $\begin{array}{l}\text { The local } \\
\text { authority did } \\
\text { not handle a }\end{array}$ & Yes & $\begin{array}{c}\text { Emotional } \\
\text { harm }\end{array}$ & $\begin{array}{c}\text { Act with respect } \\
\text { to the accusations } \\
\text { of the local }\end{array}$ & $\begin{array}{c}\text { Direct } \\
\text { tortfeasor }\end{array}$ & $\begin{array}{l}\text { This court judgment adopts a } \\
\text { liability-limiting approach with } \\
\text { respect to the boundaries of the }\end{array}$ \\
\hline
\end{tabular}

\footnotetext{
${ }^{68}$ JD v. East Berkshire Community Health NHS Trust [2005] 2 AC 373 (HL).

${ }^{69}$ Home Office v. Dorset Yacht Co. Ltd [1970] AC 1004 (HL).

${ }^{70}$ X \& Y v. London Borough of Hounslow [2009] EWCA Civ 286 (QB).

${ }^{71}$ X v. Bedfordshire County Council [1995] 2 AC 633 (HL).

${ }^{72}$ For an in-depth analysis of the reasoning leading to this conclusion, see M. Hall, The Liability of Public Authorities for the Abuse of Children in Institutional Care: Common Law Developments in Canada and the United Kingdom, 14 Int'1 JL Pol'y \& Fam. 281 (2000).
} 


\begin{tabular}{|c|c|c|c|c|c|c|c|}
\hline & $\begin{array}{l}\text { County } \\
\text { Council }^{73}\end{array}$ & $\begin{array}{l}\text { confrontation } \\
\text { between its } \\
\text { employees and } \\
\text { a school } \\
\text { headmistress } \\
\text { appropriately, } \\
\text { causing the } \\
\text { latter emotional } \\
\text { harm. }\end{array}$ & & & $\begin{array}{l}\text { authority's } \\
\text { employees } \\
\text { against the } \\
\text { headmistress; } \\
\text { Omission with } \\
\text { respect to how } \\
\text { the crisis was } \\
\text { handled. }\end{array}$ & & $\begin{array}{l}\text { applicability of the discretionary } \\
\text { exception. }\end{array}$ \\
\hline 2. & $\begin{array}{l}\text { Glaister v. } \\
\text { Appleby- } \\
\text { in- } \\
\text { Westmorla } \\
\text { nd Town } \\
\text { Council }^{74}\end{array}$ & $\begin{array}{l}\text { Liability of local } \\
\text { authority for } \\
\text { harm caused by } \\
\text { horse to visitor } \\
\text { at horse fair. }\end{array}$ & No & $\begin{array}{l}\text { Physical } \\
\text { harm }\end{array}$ & Omission & $\begin{array}{l}\text { Direct } \\
\text { tortfeasor }\end{array}$ & $\begin{array}{l}\text { The claim was rejected, on the } \\
\text { grounds of an absence of a special } \\
\text { relationship of proximity and due } \\
\text { to the distinction between the } \\
\text { omissions of the local authority and } \\
\text { between its acts. }\end{array}$ \\
\hline 3. & $\begin{array}{l}\text { Haddow v. } \\
\text { Secretary } \\
\text { of State for } \\
\text { the } \\
\text { Environme } \\
\mathrm{nt}^{75}\end{array}$ & $\begin{array}{l}\text { Misrepresentati } \\
\text { on by public } \\
\text { authority. }\end{array}$ & No & $\begin{array}{l}\text { Economic } \\
\text { loss }\end{array}$ & Act & $\begin{array}{l}\text { Direct } \\
\text { tortfeasor }\end{array}$ & $\begin{array}{l}\text { The court dismissed the case, in } \\
\text { particular in light of its reluctance to } \\
\text { award compensation for pure } \\
\text { economic loss. }\end{array}$ \\
\hline 4. & $\begin{array}{l}\text { O'Rourke } \\
\text { v. Camden } \\
\text { London } \\
\text { Borough } \\
\text { Council }^{76}\end{array}$ & $\begin{array}{l}\text { Failure of the } \\
\text { social services } \\
\text { in caring for } \\
\text { homeless } \\
\text { persons. }\end{array}$ & No & $\begin{array}{l}\text { Physical } \\
\text { harm and } \\
\text { emotional } \\
\text { harm }\end{array}$ & Omission & $\begin{array}{l}\text { Direct } \\
\text { tortfeasor }\end{array}$ & $\begin{array}{l}\text { The court precluded liability, in } \\
\text { spite of the authority of the social } \\
\text { services to care for homeless } \\
\text { persons and to monitor their } \\
\text { situation, that is, in spite of the } \\
\text { existence of a legislative mandate. }\end{array}$ \\
\hline 5. & $\begin{array}{l}\text { Rowling v. } \\
\text { Takaro } \\
\text { Properties } \\
\text { Ltd }^{77}\end{array}$ & $\begin{array}{l}\text { Erroneous } \\
\text { interpretation } \\
\text { by public } \\
\text { authority of a } \\
\text { statutory } \\
\text { provision. }\end{array}$ & No & $\begin{array}{l}\text { Mainly } \\
\text { economic } \\
\text { loss }\end{array}$ & Act & $\begin{array}{l}\text { Direct } \\
\text { tortfeasor }\end{array}$ & $\begin{array}{l}\text { The claim was rejected, mainly in } \\
\text { view of the broad discretion vested } \\
\text { in public authorities in such } \\
\text { matters. }\end{array}$ \\
\hline
\end{tabular}

\section{Summary of this area of activity}

The need for this residual category supports the insight that the twentieth century begat a policy model based on the exercise of extensive government power in social and economic life. Public authorities have fixed, broad jurisdiction over a wide range of social and economic activity - so much so that there are few fields that the modern state leaves untouched. That is why I decided to include in this residual category those court judgments that clearly do not belong to any of the six categories previously discussed. As can be seen, here too, English courts tend to preclude the imposition of tort liability on public authorities.

\section{C.3 Analysis and conclusions}

Analysis of the data in Part C.2 reveals that in all the areas of government activity examined above, English court judgments tended to preclude the tort liability of public authorities. In two categories - maintenance of the stability of financial institutions; and assurance of the safety of public ways - liability was precluded in all the cases deliberated. In three categories - issue of licenses and permits; security and emergency services; and the general liability of public authorities for activity within their jurisdiction - a clear tendency is discernable to preclude liability, the latter being imposed in only a small minority of cases. Only in two categories - the building sector; and child protection - is a relatively balanced picture reflected. This liability-limiting approach is the outcome of diverse considerations that emerge from the aforementioned judgements, including concern about over-deterrence of public authorities, the unleashing of a torrent of claims, including frivolous ones, disruption of ongoing government activity, and harm being caused to the principle of the separation of powers. These considerations

\footnotetext{
${ }^{73}$ Connor v. Surrey County Council [2010] 3 All ER 905.

${ }^{74}$ Glaister v. Appleby-in-Westmorland Town Council [2010] PIQR P6 (EWCA Civ 2009).

${ }^{75}$ Haddow v. Secretary of State for the Environment [2000] Env LR 212.

${ }^{76}$ O'Rourke v. Camden London Borough Council [1998] AC 188.

${ }^{77}$ Rowling v. Takaro Properties Ltd [1988] 1 All ER 163 (PC).
} 
led the courts in England to develop various "liability filters" for precluding public authority liability, the following being, in a nutshell, the major ones:

\section{(a) The discretionary exception}

By English doctrine, when public authorities are vested with discretion to decide whether to exercise their powers - to distinguish from a specific duty to act or to omit to act - they are not liable in tort. ${ }^{78}$ As recalled, the Anns case dealt with local authority negligence with respect to its powers to inspect and supervise building safety. In imposing liability, one of the grounds on which the court relied was the distinction (originating, as noted, in United States law) between discretion exercised at the planning level and discretion exercised at the operational level, and the determination that the negligent inspection of the foundations of the building in question - to distinguish from the decision as to the extent of supervision of building safety in general - constituted negligence at the operational level, which was subject to judicial review.

However, this approach was replaced by a cautious, traditional one that intensified over time. In many cases, adoption of the distinction between planning and execution was designed to justify failure to impose liability on the public authority. This distinction was utilized by the courts as a prominent "liability filter" in the category relating to failure to prevent crime. An example of this is the Rigby case, which dealt with the burning of the claimant's store after the police fired a canister of CS gas into it in their attempt to overcome a psychopath who was going wild on the premises. As will be recalled, in this case this distinction - between (immune) policy planning and between execution (subject to liability) - led to the preclusion of the liability of the public authority with regard to one allegation of negligence put forward by the claimant (according to which the police department should have acquired a special CS gas device), and to the imposition of liability with respect to the second allegation of negligence put forward by him (that it was out of place for police officers to open fire under these circumstances). ${ }^{79}$

Moreover, the Rowling case, as will be recalled, dealt with a negligent error by a public authority in the interpretation of a statutory provision. Here, too, the court rejected the claim under the discretionary exception, stressing once again in its judgment that some decisions made by public authorities are inappropriate for tort scrutiny, prominent examples being those entailing discretion in the allocation of limited resources or the distribution of risks. It emerges

\footnotetext{
${ }^{78}$ See for example the East Suffolk Rivers Catchment Board case, which dealt, as noted, with the negligence of the public authority with respect to the exercise of its powers to block a breach in the wall protecting the claimant against flood damage.
}

79 As we saw, the distinction in United States law between the exercise of policy discretion and between the exercises of from the court judgment that budget decisions are immune. The characterization of discretion as protected in this manner is quite broad, since a large part of public authorities' decisions can be justified as budgetary.

Finally, as we saw, the Bedfordshire County Council case dealt with the question of the responsibility of the social services for the welfare of minors and for their protection. The House of Lords rejected the claim and, relying on the discretionary exception, held that most statutory duties of local authorities entail discretion as to the manner of their execution. Decisions that fall within the boundaries of such statutory discretion cannot constitute a basis for tort liability. It further ruled in this matter that this protection can be precluded only when the claimant proves that the public authority acted with extreme unreasonability. In characterizing protected discretion, the House of Lords referred - by way of a broad definition - to decisions relating to the allocation of financial resources to competing needs and to those requiring a balance between the achievements of desirable social goals compared with the risk this entails for the public. So, it emerges from the summary of this subpart that public authorities in England enjoy a considerable degree of protection with regard to their exercise of government discretion.

\section{(b) The Public Duty Doctrine and the Requirement of a Relationship of Proximity}

In view of the extension of public authority liability to negligent omissions - as reflected in the Anns case - and in view of the vagueness of the distinction between policy and between execution, making it difficult to shape the law in this respect (as noted, the Supreme Court of the United States did away with this distinction already in the Gaubert case), English law developed additional instruments to limit the scope of liability of public authorities, with the aim of addressing concerns about the over-deterrence of public authorities, miscarriage of their discretion, and opening the floodgates of litigation, unleashing a torrent of court claims.

Two major requirements that the courts in England deliberated in a series of judgments -using them as significant "liability filters" - were the removal of general duties from the area of liability of public authorities, and the requirement of a special relationship of proximity between the tortfeasor and the injured party. These two doctrines considerably limited the scope of tort liability of public authorities. I chose to discuss these two doctrines together in view both of the conceptual relationship between them,

operational discretion became blurred over time. At the same time, it appears that English court judgments still ground themselves on this distinction. For criticism of this distinction, see W.V.H. Rogers, Winfield and Jolowicz On Tort $\left(18^{\text {th }}\right.$ ed. 2010). See, also, the discussion in this context of the aforementioned Barrett case. 
which will be shortly explained, as well as the fact that court judgments in England that refer to one of these doctrines, usually combine it with a deliberation on the other.

According to the public duty doctrine, the powers and duties of public authorities are directed to society as a collective, not to the injured party as an individual. Consequently, their breach does not provide the individual injured party with grounds for a tort claim. Put differently, the existence of a legislative mandate not only does not constitute a consideration supporting the imposition of liability on public authorities but, on the contrary, it constitutes weighty grounds for the preclusion of such liability.

The requirement of a relationship of proximity constitutes a necessary condition for recognition of the existence of a duty. In accordance with the liability-limiting approach, there are weighty grounds tilting the scales in favor of the conclusion that the requirement of a relationship of proximity is not met in the relationship between public authorities and the individual. Among these grounds can be enumerated the limited resources of public authorities relative to the multiple tasks resting on their shoulders, the precedence of the common good over that of the private individual interest, and the fact that the individual benefits greatly from that same activity of the public authority for which it is being sued. Therefore, the position of English common law tends towards the approach that the requirement of proximity is not met, certainly not a priori, in the relationship between the public authority and the individual.

It can be inferred from the aforesaid that it is no accident that these two doctrines - the public duty doctrine and the requirement of a relationship of proximity - are so frequently deliberated in combination by English courts. If the approach of English law is to view the obligations of public authorities as public duties alone, it is clear they do not usually create that same proximity required in order to impose liability. ${ }^{80}$ In other words, the fact that no relationship of proximity exists between a public authority and the individual - a necessary condition in order to impose liability - stems, among other things, from the perception of the duties of the public authority as public duties that are not directed at the individual person.

It was in this manner that the Anns doctrine was qualified in the Murphy case which, it will be recalled, concerned building plans submitted to the supervisory authority for approval. The calculations forming part of the building plans contained errors that caused severe damage to the walls and plumbing of the house. The claim was filed against the supervisory authority for negligence in checking and approving the building plans. The House of Lords ruled that in such cases, the focus must be on the question of proximity, and determined that the imposition of liability on the supervisory authority - for failure to take reasonable measures to prevent the house buyer from incurring economic loss - was, for considerations of policy, an undesirable broadening of the scope of liability.

Moreover, the O'Rourke case deliberated, as will be recalled, social services negligence while instituting a specific policy with respect to caring for the homeless. In spite of the powers and duty of the social services to provide for the homeless and to monitor their situation that is, in spite of the existence of a legislative mandate the House of Lords refused to impose tort liability here.

Police liability for failing to prevent a crime was also precluded by the application of these doctrines (and not only by means of distinguishing between planning and execution, which we came across, as will be recalled, in the Rigby case). This was also the scenario in the Hill and Brooks cases. As we saw, the claimant in the Hill case contended that the police department was negligent in conducting of an investigation of a series of murders of young women. As a consequence, the claim continued, the murderer was not apprehended, and he committed yet another murder in the home of the claimant. The claim was rejected on the grounds that the police department did not owe the public a general duty of care to prevent crimes. In the Brooks case, it will be remembered, the court followed the course set in the Hill doctrine, and exempted the police department, in like manner, from a duty of care towards the next of kin of the victim of a serial murderer who the police department failed to apprehend in a timely fashion. In keeping with this liability-limiting approach, the police department was also exempted from liability for failing to provide correct, updated information on the criminal past of a claimant who was harmed by their unlawful inclusion of details of a past incarceration in a report provided by them, as happened in the Desmond case. In a similar fashion, we saw that in the Smith case too, the claim filed against the police department, for failing to prevent the claimant's partner from attacking him in spite of his complaints and alerts, was rejected.

The Ancell case also followed the course set in the Hill case. As will be recalled, in this case the claimant was involved in a traffic accident in which he was seriously injured and his wife died. It occurred as a result of their car skidding on diesel that had spilt on the road in an earlier incident. In spite of being notified of the latter, the police department did not quickly to clean the road and return it to a condition safe for use. The Appeals Court refused to impose liability on the police department, which would have meant the imputation of a general duty to protect the users of public highways from road hazards. In this judgment too, the court elaborated on the connection between the public duty doctrine and the requirement of a relationship of proximity between the parties, and determined that the generality of the duty in this matter was inconsistent with the requirement of a relationship of proximity.

\footnotetext{
${ }^{80}$ In this context, see also the general approach adopted in the London Borough of Hounslow case.
} 
Closely tied to the Ancell case, in the Stovin case the highway authority, too, was absolved of liability by means of these doctrines. We saw that here a motorbike rider was critically injured due to the highway authority failing to properly maintain the signs within its jurisdiction, resulting in one of them being covered with vegetation so that it could not be seen. In this case, the court rejected the argument that the very fact that the highway authority operated in accordance with a legislative mandate vested in it, created that relationship of proximity required for the imposition of tort liability.

\section{(c) Pure economic loss and pure emotional harm}

Another "liability filter" concerns the type of harm. English law, too, displays a cautious, traditional approach in everything connected to the imposition of liability for pure economic loss and for pure emotional harm. ${ }^{81}$ Put differently, English law in general - much like the approach prevailing in the United States, as emerges from the analysis in Part 1 above - is reluctant to recognize the existence of the duty of care with regard to these heads of tort.

As for the limitation of public authority liability for pure economic loss, we saw that in the Murphy case, the House of Lords precluded entitlement to compensation for pure economic loss caused by the omissions of the public authority. An additional important example is the Yuen Kun-Yeu case. As we saw, in this case a bank's depositors lost their money when it collapsed. The Commissioner of Deposit-Taking Companies was sued, the cause of action being negligence in its supervision of the institution. This was a claim for pure economic loss, and it was rejected outright. ${ }^{82}$

We also saw that in the Davis case the court followed in the footsteps of the Yuen Kun-Yeu doctrine, grounding itself on it. This case, too, related to a bank that, in accordance with the law, was granted a license that was renewed yearly until it became insolvent. The claimants, the bank's depositors who lost their money, sued the regulator, whose function was to supervise the stability of the bank, for compensation for their losses. The court ruled that the Bank of England did not in any way owe a duty of care to the depositors of money in the bank that was under its supervision. Consequently, the Board of Directors could not be found liable for negligence with regard their losses - losses that stemmed from the collapse of the bank. So, this claim for compensation for pure economic loss was rejected. The Yuen Kun-Yeu and Davis doctrines were

${ }^{81}$ For a discussion on the rule of preclusion that, in many cases, prevents the imposition of liability for pure economic loss, see Pure Economic Loss: New Horizons in Comparative Law (V.V. Palmer \& M. Bussani eds., 2009).

${ }^{82}$ With respect to the discretion of the commissioner, the court determined, on page 713 , that "the commissioner had no power to control the day-to-day activities of those who caused the loss and damage. As has been mentioned the commissioner had power only to stop the company carrying subsequently enshrined in the Financial Services and Markets Act (2000), which we discussed in Part C.I. This act establishes that the Financial Services Authority and its employees enjoy statutory immunity, but this is not applicable if their activity involves bad faith.

Limitation of public authority liability for pure economic loss did not leave out the business licensing area of government activity. Even when, due to negligent supervisory and licensing practices, a public authority revoked the license of a fishing company - and thereby preventing it from continuing to operate - the cause of action was not recognized as a tort of negligence since it was a question of economic loss, as happened in the Dunlop case. Moreover, neither could the operators of a nursing home business sue the health authority for harming their financial interests due to its negligent decision to shut it down, as we learn from our discussion on the Jain case. Here, the House of Lords rejected the claim of the owners of the destroyed business to recognize the negligence of the health authority, noting that the exercise of its powers in this context was often liable to cause economic harm to business owners. At the same time, it must be remembered that the purpose of the exercise of these powers is to protect the interests of the residents of nursing homes. The court stressed that even with respect to misrepresentations by a public authority - causing economic loss to those relying on it, as in the Haddow case - this does not, as a rule, give rise to a duty of care and a tort of negligence. English court judgments also adopt a cautious, traditional approach to the imposition of liability on public authorities for pure emotional harm. We saw, for example, that a court in England, in the East Berkshire case, determined that the biological parents of a child who was erroneously removed from their custody could not sue the social services for their resulting emotional harm. On a closely related note, we also learned that in the Bury Metropolitan Borough Council case, the court determined that with respect to public policy, qualified workers engaged in child protection must feel free to carry out their designated professional role. That being the case, social services do not owe a duty of care to parents whose child was removed from their custody, suffering pure emotional harm as a result. The court even went so far as to determine that the suffering of a child separated from his mother by social services was considered a form of noncompensable distress. ${ }^{83}$

on business and the decision whether or not to do so was clearly well within the discretionary sphere of his functions."

${ }^{83}$ Moreover, as recalled, a claim filed by police officers, that a disciplinary investigation against them that was conducted negligently caused them anxiety (and harmed their reputation), was also rejected. The court precluded the existence of a duty of care in this situation - in order inter alia not to lead to over-deterrence of the police department and to enable investigators to carry out their job efficiently and free of concern. See the Calveley case. 
On the other hand, when the work of public authorities did not cause pure economic loss or pure emotional harm but, rather, physical harm, their liability was, at times, not precluded. An excellent illustration is the Perrett case, which dealt, as will be recalled, with the liability of a public authority for licensing an aircraft as airworthy. This case is somewhat reminiscent of the Varig Airlines case, referred to in our analysis of United States law. We saw that, here, the court rejected the claim of negligent supervision by the Federal Aviation Administration, in spite of a number of passengers meeting their deaths and others being injured as a result of one plane crashing and the other catching fire. Unlike this United States case, in the English Perrett case a plane crash led to the imposition of liability, and this due to negligent certification and supervision, ultimately causing the claimants physical harm.

In this spirit, a child - who due to an erroneous expert opinion was removed from the custody of his parents to a foster family, where he suffered physical abuse that led to emotional harm, as in the East Berkshire Community Health case - was also found to be entitled to compensation. Summarizing this subpart, we see that limitation of public authority liability for these two heads of tort - pure economic loss and pure emotional harm - is a highly powerful "liability filter", in particular in light of the fact that, in a large portion of the cases, it was precisely the work of the local authorities that caused these kinds of harm.

(d) Distinguishing between the acts and the omissions of local authorities

The court judgments presented in Part C.2 show that an additional "liability filter" can be portrayed as existing in English law, namely, the approach that is reluctant to impose liability for the pure omissions of the tortfeasor. ${ }^{84}$ This approach is characterized by the determination that a duty cannot be imposed on someone to act in the defense of another, barring several exceptions. The main situations where this rule of preclusion is qualified are when a special relationship exists between the tortfeasor and between the injured party, and when the defendant assumes responsibility to ensure the injured party is not harmed by that same hazard created by another. However, the readiness of English law to impose liability for the omissions of the tortfeasor - even within the boundaries of the aforementioned exceptions - is very low when the tortfeasor is a public authority. Thus, as we saw in the Stovin case, the court rejected the claim of a motorbike

${ }^{84}$ A true omission is characterized by failure of the defendant to prevent a hazard created by another entity from causing harm to the injured party, to distinguish from failure to prevent a hazard created by the defendant itself from causing harm to the injured party.

${ }^{85}$ The rhetoric adopted in the Stovin case shows that, according to the House of Lords, not even a single exception to the rule of preclusion existed. First, it characterized the duty owed by the highway authority in this case as a public duty and, as such, not creating that special relationship allowing for the rider critically injured due to the highway authority failing to properly maintain the signage within its jurisdiction and resulting in one of the signs being covered with vegetation so that it was not visible. In this case, the House of Lords recognized the rule of preclusion as applicable to omissions by the highway authority. ${ }^{85}$

The Stovin case paved the way for the ruling in the Gorringe case. It will be recalled that the later involved a claim filed against a local authority responsible for the maintenance of a country road. The injured party, who was driving at high speed towards the top of a hill, collided with a bus, and suffered severe physical harm. He claimed that the failure of the local authority to place a "slow" sign on the road constituted negligence. Applying the Stovin doctrine, the court ruled that the existence of a duty of care in tort could not be inferred merely from the existence of a wider public duty. The duty of care in negligence, it determined, could not arise "parasitically" out of a statutory duty that is imposed on the public authority. This case, too, illustrates the reluctance of English law to impose liability on public authorities for their omissions.

We saw that the public duty doctrine and the requirement of proximity helped the courts in England to limit the scope of liability of public authorities providing security and emergency services. This third "liability filter" joins them, and it appears that together they create a wide, tight protective net. First, the courts determined that public authorities providing security and emergency services are not liable in tort for their pure omissions to prevent a hazard created by another from causing harm (that is, adoption of the rule of preclusion). Second, they also determined that the fact that public authorities operate according to the terms of a mandate, both general and public, does not create that special relationship (that is, non-fulfillment of the first exception to the rule of preclusion). Third, an approach is reflected that a mandate, normally, does not turn a public authority into an entity that assumed responsibility to guarantee the welfare of the injured party (non-fulfillment of the second exception to this rule). For the issue at hand, this approach raises problems because we are talking of public authorities whose whole existence and purpose is to provide security and emergency services. However, as noted in our opening words, the readiness of English law to impose liability for the omissions of public authorities, even in the framework of the exceptions, is low.

imposition of liability for the omissions of the tortfeasor. The House of Lords also rejected the contention that the very fact that the highway authority operated according to a legislative mandate vested in it was what created that proximity required in order to impose liability on it. Second, and closely related to this, the House of Lords opined that the fact that the highway authority was given a mandate did not turn it into an entity that assumed responsibility to guarantee the welfare of the injured party. 
We saw, likewise that in the Hill case, the claim filed against the police department for its omission in failing to prevent a crime, was rejected. The Brooks case met the same fate. We also saw that in the Smith case, the claim filed against the police department for failing to prevent the claimant's partner from attacking him in spite of his complaints and alerts, was rejected. This case sheds light on the extent of protection for their omissions enjoyed by the security and emergency services in England. For, the complaints and alerts of the injured party created that same special relationship that rebuts the rule of preclusion. As mentioned, this rule was also applied to the work of the fire services, in the Capital and Counties plc case, where the injured party suffered property damage due to the fire brigade arriving late because of the negligence of the driver. The claimant was not awarded compensation on the basis of the rule limiting the liability of public authorities for their omissions. In the $\mathbf{O}^{\prime}$ Rourke case, too, as we saw, the negligence claim filed with respect to the omissions of the social services in caring for the homeless was also rejected.

To summarize, this subpart reveals that English law casts a broad, significant protective shield over the omissions of tortfeasors. This protection assumes special meaning when the latter are public authorities, since the harms caused by them in a large part of the cases stem from their omissions. Moreover, the readiness of English law to impose liability for the omissions of public authorities - even within the framework of the exceptions to the rule of preclusion - is also low.

(e) The (lack of) influence of the judgments of the Convention for the Protection of Human Rights and Fundamental Freedoms

As we saw in Part C.1, England is subject, as of 2000, to the European Convention on Human Rights and to the European Court of Human Rights, in a manner that also authorizes English courts to determine inconsistencies. The judgments of the European Court of Human Rights, together with the provisions of the English Human Rights Act, may have some impact on the considerations of the House of Lords, which in turn impact the extent of integration of human rights in the array of considerations with respect to the duty of care in the tort of negligence. Section 8(1) of the Human Rights Act ("Judicial remedies"), determines:

In relation to any act (or proposed act) of a public authority which the court finds is (or would be) unlawful, it may

\footnotetext{
${ }^{86}$ Osman v. Ferguson [1993] 4 All ER 344.

${ }^{87} \mathrm{On}$ the implications of the Osman case for English tort law, see G. Monti, Osman v. UK - Transforming English Negligence Law into French Administrative Law? 44 Int'1 \& Comp. L.Q. 757 (1999). On the complexity of combining all the arrangements, both national and international, into a single whole, see the report of the Law Commission, "Remedies Against Public Bodies", viewable

at

http://www.justice.gov.uk/lawcommission/docs/Remedies Public Bodies Scoping.pdf (link last checked on February 19, 2020). On the dialogue between the English legal system and the European Court of Human Rights subsequent to the Osman case, see also Gibson v. Chief Constable of Strathclyde [1999]
}

grant such relief or remedy, or make such order, within its powers as it considers just and appropriate.

According to the provisions of this section, if a public authority unlawfully harms a right protected under the European Convention, the court is authorized to consider granting relief, including compensation, for this harm. This section thereby creates a cause of tort action against public authorities, with the imposition of tort liability likely to stem from human rights laws.

The landmark judgment on this issue was handed down in the Osman v. Ferguson case, ${ }^{86}$ relating to an incident where an English teacher attacked his student, Ahmet Osman, and murdered the latter's father and two other people. The teacher was subsequently diagnosed as prone to psychotic episodes and admitted to a psychiatric hospital. The widow and her children sued the London Metropolitan Police for consistently ignoring the complaints lodged by the family of the murdered man. Although the European Court of Human Rights did not rule that the police department acted negligently, it held that the English court - which determined that the family had no cause of action whatsoever against the police department - deviated from the provisions of the European Convention, which grant the right to be heard in court, and it awarded compensation for that. ${ }^{87}$

Another example relates to the Bedfordshire case, to which we referred in the previous subparts. As will be recalled, here the House of Lords refused to accept the claim filed by injured parties that they were victims of abuse and neglect on the part of their parents and that, although the social services knew about this, they failed to protect them. In the $\mathbf{Z}$ v. UK case, ${ }^{88}$ the European Court of Human Rights determined that the English court's rejection of the claim - that social services failed to appropriately protect minors - constituted a violation of obligation anchored in the European Convention to award compensation for this.

In spite of these cases, it seems to me we should not exaggerate with regard to the degree of influence of the European Convention on the scope of liability of local authorities in England. An example of the limitations of its power is the Kay v. Lambeth LBC judgment, ${ }^{89}$ which dealt with the omission of social services to provide accommodation for the homeless. In spite of the provisions of Article 8 of the European Convention which anchors the right to a home ${ }^{90}$ - the House of Lords determined that social services were not obligated to provide housing and a place to live when this interest clashed with the right to property. ${ }^{91}$ So, the impact of the European Convention on widening the scope of local authority liability in England is limited.

ScotCS 61 (Scotland); the Barrett case, footnote 65 above; and Phelps v. London Borough of Hillingdon [2001] 2 AC 619 (HL).

${ }^{88} \mathrm{Z}$ and Others v. The United Kingdom [2001] 2 FCR 246 (ECHR).

${ }^{89}$ Kay v. Lambeth LBC [2006] 2 AC 465.

${ }^{90}$ Article 8(1) of the European Convention states, "Everyone has the right to respect for his private and family life, his home and his correspondence."

${ }^{91}$ For further reading on the limited impact of the European Convention on English law, see the decision of the House of Lords in the Van Colle case (Van Colle v. CC Hertfordshire Police [2009] AC 255). 
To summarize this part, it emerges that, as a whole, the tendency of the courts in England until the mid-1980s was to widen the scope of liability, reaching its peak in the Anns case, where the local authority was held liability for negligence in the inspection and supervision of building safety, in spite of the harm caused being pure economic loss. As of the mid1980s, considerations came to the fore once again about the over-deterrence of local authorities, the unleashing of a torrent of claims, including frivolous ones, disruption of ongoing government activity, and harming the principle of the separation of powers. As corollary to this, the traditional liability-limiting doctrine gained momentum in the full range of activity of public administration. This traditional approach utilizes diverse "liability filters" that considerably limit the boundaries of public authority liability in every sphere of government activity, a state of affairs that continues until this very day. A certain weakening of this traditional approach can indeed be identified as of 2000, when the Human Rights Act came into force in England, incorporating the rights set out in the European Convention for the Protection of Human Rights and Fundamental Freedoms. However, the power and influence of the latter on the scope of public authority liability in England is limited, and does not appear to considerably gnaw at its traditional liability-limiting approach.

\section{Part D: Overall Conclusion}

Over 50 court judgments were analyzed in this article, with the aim of tracing the level of public agency tort liability in the United States and in England. The technique employed for the analysis of the abundant court judgments was to classify them according to areas of government activity. This comprehensive analysis showed that there are both similarities and differences between the prevalent approaches to this issue in United States law and in English law. With respect to the similarities, the remnants of the traditional approach, upholding the principle of the doctrine of sovereign - or crown - immunity stand out in both legal systems. The analysis of case law in these two countries showed that, today too, public agencies enjoy extensive protection against tort claims, and the general approach of their legal systems was, and remains, one that limits liability. We saw that in the United States this liability-limiting approach is reflected at all three government levels - federal, state and municipal, and the main "liability filter" through which court judgments limit the scope of liability of public agencies is the discretionary exception provision anchored in Section 2680(a) of the Federal Code. Analysis of United States law showed that the range of reasonability accorded to the various kinds of government discretion is exceedingly broad, so much so that it can be assessed that the judicial review of public agencies through tort law is ineffectual. We saw that in England, too, the liability-limiting approach implemented by the courts by means of a range of "liability filters" is very conspicuous, the analysis of judgments handed down showing that in each area of government activity examined, public authorities tended to be precluded from liability.

With respect to the differences, the discretionary exception was, and remains, the major "liability filter" in the United States. We saw that the Federal Code precludes the exercise or failure to exercise discretion in the performance of a function or duty from the boundaries of liability. This legal instrument was used to preclude liability in cases where agencies caused economic loss, property damage or even extensive physical harm. Moreover, liability was also precluded when the harm caused by the omissions of the agency was a result of its active acts. Furthermore, the discretionary exception was applied both when the government was an indirect tortfeasor and even when it was in the capacity of a direct tortfeasor. Finally, we saw the government was precluded from liability on the grounds of this exception regardless of whether the injured party was an adult or whether it was a matter of a minor who suffered physical harm. While English law, on the other hand, also extends some protection to local authorities in the exercise of government discretion, it is quite limited compared to the United States. At the same time, additional "liability filters", which were discussed in Part C, constitute crucial factors in limiting its scope - namely, the public duty doctrine and the requirement of proximity; the preclusion of liability for pure economic loss or pure emotional harm; and the distinction between negligence by an act and negligence by omission.

It can be said that the overall picture is that in both the United States and in England the tort liability of public agencies is limited in scope. Even the "liability filters" through which the regime of restricted, limited liability is implemented are similar. The difference is in the frequency and combination of the different liability filters used by each legal system.

This delineation of the level of liability in both legal systems raises the question why this is so. Put differently, why did diverse concerns and considerations lead to the saliency in the United States and England of the remains of the traditional approach, siding with the doctrine of the immunity of the sovereign? Although this question deserves separate research, one possible explanation relates, in a nutshell, to the perception of the goal of tort compensation. There is a fundamental difference between a legal systems that views compensation (that is, the principle of restitutio ad integrum) as a means of achieving a goal of tort law, and between one where tort compensation is viewed as an independent goal. When compensation constitutes solely a means - for the achievement of other goals, such as deterrence and justice - it is to be applied only when it serves the goals it was designed to realize. Thus, an approach that views compensation as a means, and distributive justice, for example, as a goal, will only impose liability on the tortfeasor when this contributes to the just global distribution of wealth or resources in society. In contrast, according to an approach that views compensation, and the principle of restitutio ad integrum, as an independent goal, liability is to be imposed on the tortfeasor irrespective of the question whether this course contributes to the achievement of other goals, such as deterrence and justice. Consequently, it appears that the United States and English legal systems view tort compensation as a means for the achievement of the goals of tort law, not as an independent goal.

$--0--$ 